\title{
Geochemistry of cassiterite and wolframite from tin and tungsten quartz veins in Portugal
}

\author{
A.M.R. Neiva * \\ Department of Earth Sciences, University of Coimbra, 3000-272 Coimbra, Portugal
}

Received 9 August 2005; accepted 29 May 2006

Available online 4 October 2007

\begin{abstract}
Cassiterite and wolframite compositions from $\mathrm{Sn}>\mathrm{W}$ - and $\mathrm{W}>\mathrm{Sn}$-bearing quartz veins in Northern and Central Portugal are compared to provide evidence on fluid compositions. In $\mathrm{Sn}>\mathrm{W}$-bearing quartz veins, euhedral cassiterite shows sequences of alternating parallel darker and lighter zones. The darker zones are pleochroic, oscillatory zoned, exhibit exsolutions of columbite and ixiolite and are richer in $\mathrm{Nb}$, Ta and $\mathrm{Fe}$ than the lighter zones which consist of nearly pure $\mathrm{SnO}_{2}$. Cassiterite from $\mathrm{W}>\mathrm{Sn}$-bearing quartz veins is usually zoned, with homogeneous and slightly pleochroic darker zones, which are chemically similar to lighter zones. Both zones have inclusions of rutile and rare ilmenite. The darker zones of cassiterite from the former veins are richer in $\mathrm{Nb}$, Ta and $\mathrm{Fe}$ contents and poorer in Ti than the darker and lighter zones of cassiterite from the latter veins. This is attributed to differences in the composition of magmatic hydrothermal fluids.

Wolframite compositions from $\mathrm{Sn}>\mathrm{W}$ - and $\mathrm{W}>$ Sn-bearing quartz veins do not show any significant distinction, because they precipitate from relatively similar magmatic hydrothermal fluids. In some deposits, most wolframite crystals are homogeneous, but others are heterogeneous. Inner patches, rich in a hübnerite component, rarely occur in crystals from the Filharoso and Panasqueira deposits. Zoned crystals, showing an increase in Fe and a decrease in Mn from core to rim, were found in the Vale das Gatas deposit. Complex oscillatory zoned crystals occur. In the Carris deposit, later wolframite contains inclusions of scheelite, partially replaces it and is richer in $\mathrm{Fe}$ and poorer in $\mathrm{Mn}$ than earlier wolframite. Wolframite from $\mathrm{Sn}>\mathrm{W}$-bearing quartz veins in the Argozelo deposit and $\mathrm{W}>$ Sn-bearing quartz veins from Vale das Gatas and Panasqueira deposits has significant $\mathrm{Nb}$ content. This does not depend on the Fe and $\mathrm{Mn}$ content of the wolframite, but W content is negatively correlated with $\mathrm{Nb}$ content. Only very rare single crystals of wolframite show an increase in $\mathrm{W}$ and a decrease in $\mathrm{Nb}$ from core to rim. $\mathrm{Sn}>\mathrm{W}$-bearing quartz veins contain wolframite poorer in $\mathrm{Nb}$ than the darker zones of cassiterite, which exsolved columbite and ixiolite. In W $>$ Sn-bearing quartz veins from Panasqueira and Vale das Gatas, the wolframite has a higher $\mathrm{Nb}$ content than the cassiterite, which contains rutile inclusions enriched in $\mathrm{Nb}$, because cassiterite and wolframite are derived from two distinct magmatic hydrothermal fluids of different age. The fluid responsible for wolframite precipitation will have a similar composition to that resulting from the evolution of the fluid responsible for cassiterite precipitation in the $\mathrm{Sn}>$ W-bearing quartz veins.

(C) 2008 Published by Elsevier B.V.
\end{abstract}

Keywords: Cassiterite; Columbite; Ixiolite; Rutile; Wolframite; Portugal; Ore-forming fluids

\footnotetext{
* Fax: +351 239860501 .

E-mail address: neiva@dct.uc.pt.
}

\section{Introduction}

Most tin and tungsten deposits are spatially associated with granitic rocks. Tin deposits that contain subordinate tungsten have been reviewed by Heinrich (1990), while 
the deposits in which tungsten is the dominant metal and the next most abundant metal is generally tin have been reviewed by Wood and Samson (2000). In general, these deposits have multiple stages of mineralization, but cassiterite and wolframite commonly occur in the oxidesilicate stage, which occurs early in the paragenesis and is often postdated by a sulphide-rich stage.

Cassiterite and wolframite occur frequently in deposits of northern and central Portugal. The most intense period of exploitation of Sn and W deposits in Portugal took place from 1939 to 1958 . About 40,000 t of cassiterite and 69,249 t of wolframite were exploited (Carneiro, 1959). From 1937 to 1986, approximately $1570 \mathrm{t}$ of cassiterite and $2826 \mathrm{t}$ of wolframite were exploited from the mines of Argozelo, Carris and Vale das Gatas (based on data supplied by Portuguese INETI). Panasqueira is one of the largest tungsten mines in Europe and nowadays, it is the only Portuguese mine exploiting wolframite. At Panasqueira, approximately $70,000 \mathrm{t}$ of wolframite were concentrated from 1947 to 1986 . About $435 \mathrm{t}$ of cassiterite and $4070 \mathrm{t}$ of chalcopyrite were also concentrated between 1982 and 1986 (Polya, 1989). Nowadays, about 50,000 t of 'tout-venant' are processed per year (information given by Portuguese INETI).

In northern and central Portugal, there are several hypothermal quartz veins containing both cassiterite and wolframite. These veins intersect Cambrian, Ordovician and Silurian metapelites; they surround and, less commonly, cut granites (Cotelo Neiva, 1944). The majority of the deposits are related to Hercynian S-type granites which have significant Sn contents (Neiva, 2002), but a number of them are associated with a Hercynian I-type granite.

Several studies have determined cassiterite compositions by electron microprobe (e.g., Černý et al., 1985, 2004; Černý and Ercit, 1989; Neiva, 1996; Novak, 1999). In contrast, the number of published electron microprobe analysis of wolframite are limited, and determinations of minor elements in wolframite (e.g., Gu and Schröcke, 1986; Polya, 1988; Mignardi et al., 1998) are relatively rare.

This contribution presents new compositions, obtained by electron microprobe, of cassiterite and wolframite crystals from hypothermal quartz veins in Portugal which contain both ore minerals (Fig. 1), with a view to achieving an understanding of zoning, minor element chemistry, and crystal-chemistry of cassiterite and wolframite. Cassiterite compositions from some Portuguese deposits have previously been determined by Neiva (1996). The compositions of both ore minerals in $\mathrm{Sn}>\mathrm{W}$ - and $\mathrm{W}>\mathrm{Sn}$-bearing quartz veins are

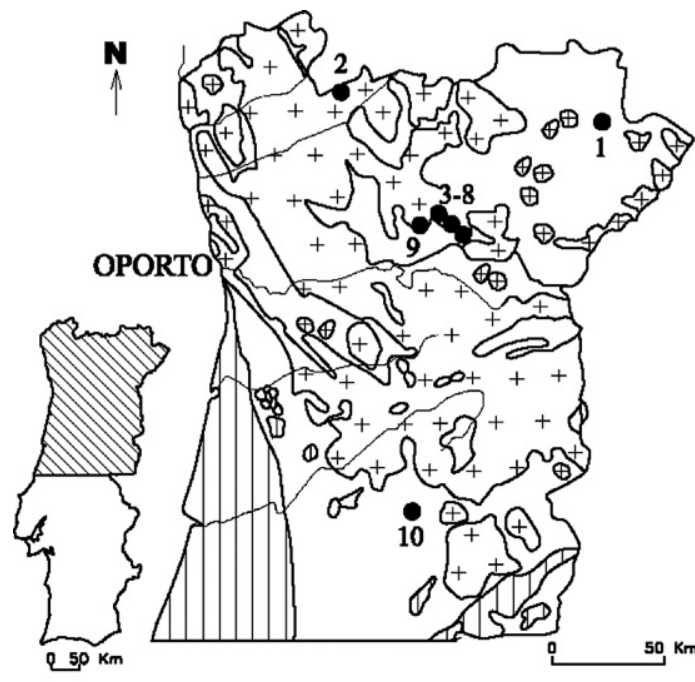

\section{- Sn- and W-bearing quartz veins Mesozoic and Cenozoic ${ }_{+}^{+}+$Hercynian granites Precambrian and Paleozoic}

Fig. 1. Location of ten $\mathrm{Sn}$ and $\mathrm{W}$ deposits from Northern and Central Portugal included in this study. $\mathrm{Sn}>\mathrm{W}$-bearing quartz veins: 1-Argozelo (Argozelo, Vimioso); $\mathrm{W}>$ Sn-bearing quartz veins: 2-Carris (Cabril, Montalegre), 3-Carvalhal (Cheires, Alijó), 4-Soutelinho (Favaios, Alijó), 5-Filharoso (Presandães, Alijó), 6-S. Domingos (Alijó, Alijó), 7-Folgar (S. Mamede de Ribatua, Alijó), 8-Bouço (S. Mamede de Ribatua, Alijó), 9Vale das Gatas (S. Lourenço de Ribapinhão e Souto Maior, Sabrosa), 10-Panasqueira (Aldeia de S. Francisco e S. Jorge da Beira, Covilhã e Fundão). For each, the parish and municipality are given in brackets.

compared and provide information on the compositions of the ore-forming fluids.

\section{Geological setting}

Most of the tin and tungsten quartz veins from northern and central Portugal intersect the Cambrian schistmetagraywacke complex, which consists of schist with intercalations of metagraywacke and some lenses of marble. Some of the veins intrude Ordovician and Silurian schist sequences, which also contain carbonates.

In general, these veins are associated with Hercynian muscovite-biotite granites and muscovite granites, 336 to $287 \mathrm{Ma}$ in age, which are strongly differentiated, enriched in $\mathrm{Sn}, \mathrm{Rb}, \mathrm{Cs}, \mathrm{Li}$ and $\mathrm{F}$, and impoverished in $\mathrm{Ti}$, $\mathrm{Cr}, \mathrm{V}, \mathrm{Ni}, \mathrm{Co}, \mathrm{Sr}$ and $\mathrm{Ba}$. These granites usually contain between 18 and 100 ppm Sn and 3 and 9 ppm W. In general, muscovite retains a higher percentage of total granite tin than biotite. The granites are peraluminous 
$(\mathrm{A} / \mathrm{CNK} \geq 1.1)$, display negative Eu anomalies and show isotopic values $\left({ }^{87} \mathrm{Sr} /{ }^{86} \mathrm{Sr}\right) \geq 0.708, \varepsilon \mathrm{Nd}(\mathrm{T})$ of -4.5 to -16.4 and $\delta^{18} \mathrm{O}$ values between 11.0 and $12.8 \%$. These granites are typical S-type granites, generated by partial melting of heterogeneous metasedimentary materials (Neiva, 2002). However, rarely $\mathrm{W}>$ Sn-bearing quartz veins are associated with a Hercynian peraluminous biotite granite of I-type (Neiva, 2002).

Throughout the region, the $\mathrm{Sn}>\mathrm{W}-$ and $\mathrm{W}>\mathrm{Sn}-$ bearing quartz veins have a similar mineralogical association. However, columbite and ixiolite were only found in the veins containing more cassiterite than wolframite, whereas rutile and ilmenite are only significant in the veins containing more wolframite than cassiterite. In general, cassiterite, columbite and ixiolite occur close to, and associated with, muscovite selvages along the vein-wallrock contacts, particularly along vein-schist contacts. Cassiterite is also associated with muscovite within the vein, whereas wolframite is distributed throughout the veins. As a rule, wolframite is later than cassiterite. Scheelite also occurs in the veins, but in much smaller amounts than wolframite; in general, it also postdates wolframite. All the veins contain carbonates (siderite, dolomite and calcite), which belong to the last hypogene stage. At the walls of the quartz veins, there are notable enrichments in quartz, muscovite, sulphides and locally also in tourmaline. Scheelite also occurs here, in greater abundance than in the quartz veins themselves. It replaces calcite within the schist.

\subsection{Argozelo}

The Sn-W mine of Argozelo consists of 27 mineralized quartz veins which cut a muscovite-biotite pelitic schist of Silurian age. Hercynian two-mica S-type granites occur nearby. The veins range in width from a few $\mathrm{cm}$ to $1 \mathrm{~m}$; most are between 15 and $40 \mathrm{~cm}$. In general, they are 180 to $240 \mathrm{~m}$ in length. They dip steeply $\left(70-85^{\circ}\right)$ with a N $10-20^{\circ} \mathrm{E}$ strike, but in the northeastern part of the mine, they dip less steeply $\left(50^{\circ}\right)$ and strike $\mathrm{N} 20-30^{\circ} \mathrm{E}$.

At the contact between vein and wallrock, the veins contain varying amounts of intergrown cassiterite, quartz, columbite, ixiolite and arsenopyrite, forming selvages up to $3 \mathrm{~cm}$ in thickness. The main quartz veins are made up of massive quartz with scattered pockets containing mainly wolframite, pyrrhotite, arsenopyrite, pyrite, sphalerite and chalcopyrite. The paragenetic sequence can be divided into four principal stages of mineralization: (1) muscovite selvage formation (quartz I, muscovite, tourmaline, columbite, ixiolite, cassiterite, arsenopyrite I); (2) the main oxide-silicate stage (wolframite, quartz II, arsenopyrite
II); (3) the main sulphide stage (quartz III, pyrrhotite, pyrite, arsenopyrite III, chlorite, apatite, sphalerite, chalcopyrite, galena); (4) the late carbonate stage (siderite, dolomite, calcite). The country rock in contact with the vein system is pervasively infiltrated with quartz veinlets containing trace amounts of scheelite and sulphides.

\subsection{Carris}

The W-Sn mine of Carris consists of mineralized quartz veins, which intruded a fine-grained biotite I-type granite of peraluminous character $(\mathrm{A} / \mathrm{CNK}=1.02-1.06)$ and large negative $\mathrm{Eu}$ anomaly. The granite has been dated at $302 \pm 4$ Ma by whole-rock $\mathrm{Rb}-\mathrm{Sr}$ methods and has a $\left({ }^{87} \mathrm{Sr} /{ }^{86} \mathrm{Sr}\right)_{0}$ ratio of $0.7052 \pm 0.0005$ indicating an important mantle contribution (Neiva, 1993).

The $\mathrm{W}>$ Sn-bearing quartz veins are orientated $\mathrm{N}^{\circ}{ }_{-}$ $10^{\circ} \mathrm{E}$, are 800 to $1000 \mathrm{~m}$ in length and range in width from 20 to $50 \mathrm{~cm}$. They consist of quartz, muscovite, fluorite, tourmaline, cassiterite, wolframite, scheelite, pyrrhotite, arsenopyrite, pyrite, sphalerite, chalcopyrite, stannite, bismuthinite, molybdenite and native bismuth.

\subsection{The Alijó area and Vale das Gatas}

The $\mathrm{W}>$ Sn-bearing quartz veins from Carvalhal, Soutelinho, Filharoso, S. Domingos, Folgar and Bouço occur close to each other in a limited area (Fig. 1). The veins cut the Cambrian schist-metagraywacke complex and are associated with fine- to medium-grained porphyritic muscovite-biotite granite (muscovite $>$ biotite). The $\mathrm{S}$-type granite is peraluminous with a mean $\mathrm{A} / \mathrm{CNK}$ ratio 1.20 (e.g., Neiva, 1973).

The veins mainly strike NE-SW, but there are also veins orientated NW-SE to WNW-ESE, which are 200 to $400 \mathrm{~m}$ in length. They mainly contain quartz, cassiterite, wolframite, pyrrhotite, arsenopyrite, pyrite, sphalerite, chalcopyrite and galena, but also some rutile and ilmenite. Mineralization has produced metasomatic alteration of the schist-metagraywacke complex, resulting in muscovitization and tourmalinization in a thin zone surrounding the veins. Scheelite is observed in the veins and metasomatic schist adjacent to the veins (Neiva, 1973).

The Vale das Gatas orebody consists of a $\mathrm{W}>\mathrm{Sn}$ bearing quartz vein system located at the contact between the Cambrian schist-metagraywacke complex and the medium- to coarse-grained porphyritic muscovite-biotite granite (muscovite $>$ biotite). This $\mathrm{S}$-type granite is peraluminous (mean A/CNK ratio of 1.40), Hercynian syn-D3, and intruded the complex to produce a hornfels contact metamorphic aureole. Muscovite $\mathrm{K}-\mathrm{Ar}$ dating of 
other syntectonic granites in the area (Vilela de Matos, in press) gave the age of $323 \pm 4 \mathrm{Ma}$, whereas biotite from the same granites yielded an age of $311 \pm 9 \mathrm{Ma}$.

The mineralized quartz veins strike WNW-ESE, $30^{\circ} \mathrm{SW}$. The largest, $2.5 \mathrm{~km}$ long and up to $1 \mathrm{~m}$ thick, has been mined. The main minerals are quartz, muscovite, cassiterite, wolframite, arsenopyrite, pyrrhotite, pyrite, sphalerite, chalcopyrite, stannite, galena, Ag-sulphosalts and fluorite. The veins also carry rutile and ilmenite. Three main paragenetic stages were distinguished. Cassiterite belongs to the first stage; wolframite belongs to both the first and second stages (Vilela de Matos, in press). The veins produced muscovitization at the wallrock contact; this is seen better at the contact with schist rather than granite.

\subsection{Panasqueira}

The Panasqueira orebody extends over an area of $6 \mathrm{~km}$ and is composed of more than $1000 \mathrm{~W}>$ Sn-bearing quartz veins, which are subparallel, nearly horizontal, a few $\mathrm{mm}$ to over $1 \mathrm{~m}$ in thickness and extending 10 to $20 \mathrm{~m}$ laterally, exceptionally $>100 \mathrm{~m}$. The veins cut the Cambrian schist-metagraywacke complex and the greisenized cupola of the batholith (Kelly and Rye, 1979; Bussink, 1984; Polya, 1989). This batholith consists of a Hercynian fine- to medium-grained, porphyritic muscovite-biotite granite (muscovite $>$ biotite), which is peraluminous with a molecular $\mathrm{ACNK}=\mathrm{Al}_{2} \mathrm{O}_{3} /\left(\mathrm{CaO}+\mathrm{Na}_{2} \mathrm{O}+\mathrm{K}_{2} \mathrm{O}\right)$ ratio of 1.33 , an initial ${ }^{87} \mathrm{Sr} /{ }^{86} \mathrm{Sr}$ ratio of 0.713 and $\delta^{18} \mathrm{O}$ of $10 \%$ (Bussink et al., 1984), i.e., S-type character. The granite intruded the greenschist facies Beira schist sequence and produced a contact metamorphic aureole dominated by schist containing cordierite-biotite spots. The mineralogical and chemical changes to the granite during greisenization and the compositions of muscovite from these granites and mineralized quartz veins have been reported by Neiva (1987a,b). A silica cap occurs at the apex of the cupola and is composed mainly of quartz with subordinate amounts of muscovite, wolframite and sulphides.

The $\mathrm{W}>$ Sn-bearing quartz veins are mainly composed of quartz, tourmaline, muscovite, topaz, apatite, cassiterite, wolframite, arsenopyrite, pyrrhotite, pyrite, sphalerite, chalcopyrite, stannite, galena and carbonates, but also contain rutile and ilmenite. The paragenetic sequence of the mineralized quartz veins has been divided into four stages of mineralization 1) oxidesilicate stage, 2) main sulphide stage, 3) pyrrhotite alteration stage, and 4) late carbonate stage (Kelly and Rye, 1979), five stages (Polya, 1989) and six stages (Polya et al., 2000). The stages given by the latter authors are 1) crack-seal quartz seam, 2) muscovite selvage formation, 3) main oxide-silicate stage, 4) main sulphide stage, 5) pyrrhotite alteration stage, and 6) late carbonate stage. Stages 1, 2 and 3 are penecontemporaneous, but stage 1 precedes stage 2 , which precedes stage 3 in any single locality (Foxford et al., 1991). Cassiterite and wolframite occur in stage 1 (Kelly and Rye, 1979), but cassiterite is earlier than wolframite. Cassiterite occurs in stages 3 and 4, whereas wolframite belongs to stage 3 (Polya et al., 2000). The major and/or distinctive primary minerals of these two stages are quartz, tourmaline, muscovite, arsenopyrite, cassiterite, apatite and wolframite for the main oxide-silicate stage 3, and quartz, tourmaline, muscovite, arsenopyrite, phosphates, apatite, sphalerite, pyrrhotite, pyrite, chalcopyrite and cassiterite for the main sulphide stage 4 . The progression from oxide-dominated to base-metal sulphide paragenesis is partially attributed to the increasing importance of metasedimentary sources for the ore-forming components over time (Polya et al., 2000). However, helium trapped in wolframite and arsenopyrite was sourced in the mantle, and the mantle-derived fluids were the source of the magmatic component in the ore fluids (Burnard and Polya, 2004).

Snee et al. (1988) obtained ${ }^{40} \mathrm{Ar} /{ }^{39} \mathrm{Ar}$ dates for muscovite of $296.3 \pm 0.6 \mathrm{Ma}$ for oxide-silicate stage I comprising muscovite-rich selvages, which may either be pure or may contain variable amounts of tourmaline, cassiterite, topaz and early arsenopyrite; $294.5 \pm 0.9 \mathrm{Ma}$ for the main sulphide stage; $292.9 \pm 0.7$ Ma for oxidesilicate stage II corresponding to late intergrowths of coarse quartz, muscovite, wolframite and arsenopyrite that make up the central vein fillings; and 292.1 $\pm 0.4 \mathrm{Ma}$ for greisenization and alteration of the silica cap and 274 to $292 \mathrm{Ma}$ for the pyrrhotite alteration stage. Muscovite intergrown with wolframite has lower $\mathrm{Fe}, \mathrm{K}, \mathrm{Rb}, \mathrm{Nb}, \mathrm{Ta}$, $\mathrm{W}, \mathrm{V}$ and $\mathrm{Zn}$ contents than the muscovite of selvages associated with cassiterite (Neiva, 1987b). The Fe, W, $\mathrm{Nb}$ and $\mathrm{Ta}$ are retained in wolframite, whereas $\mathrm{Zn}$ is concentrated in sphalerite.

The $\mathrm{W} \pm$ Sn quartz veins are surrounded by three main hydrothermal zones. The first of these, adjacent to the veins, is composed of tourmaline-rich mica schist, 2 to $30 \mathrm{~cm}$ in thickness. This is surrounded by a muscoviterich zone which is much thicker than the first zone; the two zones overlap in places. The third zone is farther from the veins and consists of chlorite-muscovite schist (Bussink, 1984). The mineralogical and chemical changes during hydrothermal alteration have been studied by Bussink (1984) and Polya (1989). In places, a fine-grained tourmaline-rich rock occurs adjacent to the $\mathrm{W} \pm$ Sn quartz veins. 


\section{Analytical methods and criteria to distinguish exsolution products from included minerals}

Careful microscopic observation was undertaken prior to microanalysis of cassiterite and wolframite in polished thin sections. Electron-microprobe traverses were carried out on distinct lighter and darker zones of cassiterite found is transmitted light and also on wolframite crystals.

The oxide minerals were analyzed for major and trace elements using a Cameca Camebax electron microprobe at the Instituto Geológico e Mineiro, S. Mamede de Infesta, Portugal. Standards used include $\mathrm{SnO}_{2}(\mathrm{SnL} \alpha)$, $\mathrm{Fe}_{2} \mathrm{O}_{3}(\mathrm{FeK} \alpha), \mathrm{MnTiO}_{3}(\mathrm{MnK} \alpha$ and $\mathrm{TiK} \alpha)$, pure $\mathrm{W}$ $(\mathrm{L} \alpha), \mathrm{Ta}(\mathrm{L} \alpha), \mathrm{Nb}(\mathrm{L} \alpha)$ metals. Analyses were conducted at an accelerating voltage of $15 \mathrm{kV}$ and a beam current of 20 nA with 20 second count times; ZAF corrections were applied. Detection limits for $\mathrm{Nb}$ and $\mathrm{Ta}$ are $100 \mathrm{ppm}$ for $\mathrm{Nb}_{2} \mathrm{O}_{5}$ and $\mathrm{Ta}_{2} \mathrm{O}_{5}$; standard analytical relative errors $(2 \sigma)$ are determined to be $\pm 1.5 \%$. Some backscattered images were taken using a Leica S360 scanning electron microscope at Minho University, Portugal.

The distinction between products of exsolution and accidental inclusions was based on textural observations and on electron-microprobe traverses of the host cassiterite near the products of exsolution and inclusions. The products of exsolution occur throughout cassiterite, aligned along crystallographic faces, regularly spaced and commonly along fractures. In contrast, the accidental inclusions are solid grains trapped during mineral growth and are not the product of exsolution. They occur within the cassiterite and display no particular orientation. The values of $\mathrm{Nb}, \mathrm{Ta}, \mathrm{Fe}$ and $\mathrm{Ta} /(\mathrm{Ta}+\mathrm{Nb})$ in the zones of cassiterite which appear darker in transmitted light increase with increasing distance from exsolved $\mathrm{Nb}$ - and Ta-bearing oxide minerals. The darker zones are therefore heterogeneous, whereas the cassiterite composition is homogeneous if the crystal contains only accidental inclusions.

The chemical criterion defined by Neiva (1996) was used to distinguish the relatively pure minerals of the columbite-tantalite group from minerals of the ixiolitewodginite series, and for simplicity referred to as ixiolite here. The terminology used is based on the work of Černý and Ercit (1989).

\section{Characteristics of cassiterite and wolframite}

Euhedral cassiterite from quartz veins in which $\mathrm{Sn}>\mathrm{W}$ is zoned, showing sequences of alternating narrow, parallel, darker and lighter zones in transmitted light (Fig. 2a). The darker zones are pleochroic from $\varepsilon$ red to $\omega$ translucent and colourless, whereas the lighter zones are colourless to tan and translucent. The darker zones exhibit products of exsolution, while the lighter zones only show them in contact with the darker zones. The exsolved $\mathrm{Nb}-$ and Ta-bearing oxide minerals are typically $\leq 80 \times 50 \mu \mathrm{m}$ in size.

Euhedral cassiterite from $\mathrm{W}>$ Sn-bearing quartz veins is usually zoned in transmitted light (Fig. 2b), with slightly pleochroic darker zones from $\varepsilon$ brown to $\omega$ light brown. However, at Carvalhal (Fig. 2c) the darker zones of some crystals of cassiterite are strongly pleochroic from $\varepsilon$ red to $\omega$ translucent and colourless. Darker and lighter zones of cassiterite present accidental rutile inclusions, $\leq 30 \times 20 \mu \mathrm{m}$ in size, and rare ilmenite inclusions $(\leq 8 \times 3 \mu \mathrm{m}$ in size $)$, which are distributed uniformly. Cassiterite lacks any products of exsolution. In general, there is only a single generation of cassiterite, but two generations were found in the $\mathrm{W}>$ Sn-bearing quartz veins from Panasqueira (Polya et al., 2000).

Wolframite belongs to only one paragenetic stage, except in the Vale das Gatas deposit, where wolframite belongs to two paragenetic stages (Vilela de Matos, in press). Microscopically, most wolframite crystals are dark brown to black in colour and are homogeneous; a minority are, however, heterogeneous (Fig. 2d). Several crystals do not contain accidental inclusions. At Carris, the earlier crystals do not contain inclusions, whereas the later crystals have inclusions of scheelite, and wolframite partially replaces scheelite. Products of exsolution were not found. In general, the sulphides postdate wolframite and locally penetrated along fractures in wolframite crystals.

\section{Cassiterite compositions and zoning}

In the crystals of cassiterite from $\mathrm{Sn}>\mathrm{W}$-bearing quartz veins, the lighter zones are homogeneous and consist of nearly pure $\mathrm{SnO}_{2}$, whereas the darker zones have higher contents of $\mathrm{Nb}$, Ta and $\mathrm{Fe}$ (Table 1, analyses 1-4). The darker zones are heterogeneous and their $\mathrm{Nb}$, $\mathrm{Ta}$ and Fe contents decrease near exsolved ferrocolumbite (Table 1, analyses 1-3), manganocolumbite and titanium ixiolite with subordinate $\mathrm{W}>\mathrm{Sn}$. Despite this, backscattered electron images show no apparent chemical distinction between the lighter and darker zones. In the darker zones, Ta becomes more abundant than $\mathrm{Nb}$ with increasing distance from the exsolution products. Within the same crystal, closely-spaced darker zones show no significant chemical distinction from one another, whereas darker zones that are far apart and exhibit the same exsolution product (either columbite or ixiolite) have significant differences in their $\mathrm{Ta} /(\mathrm{Ta}+\mathrm{Nb})$ values (Neiva, 1996). 

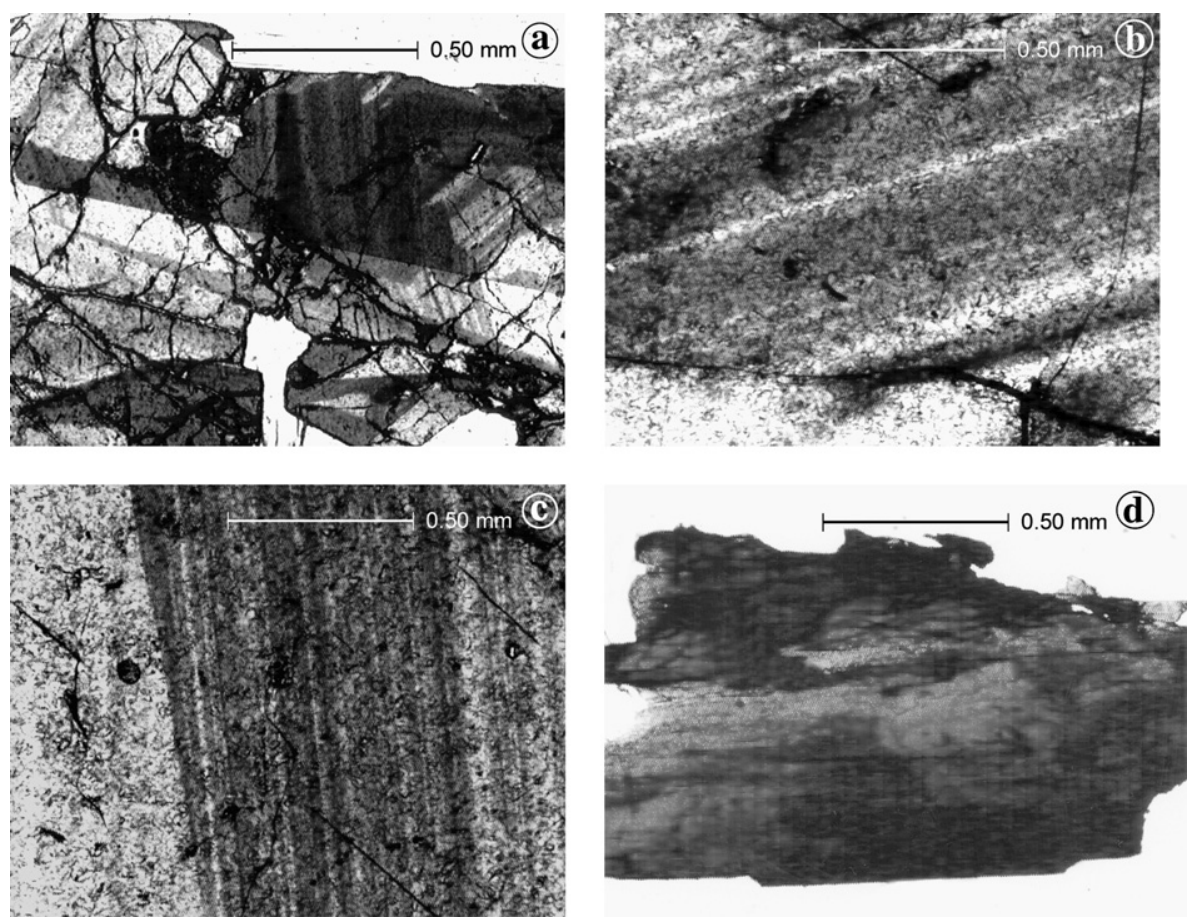

Fig. 2. Photographs of cassiterite and wolframite from northern Portugal taken in transmitted light. (a). Part of a cassiterite crystal from the Sn $>$ Wbearing quartz veins from Argozelo. (b) and (c). Part of a cassiterite crystal from the W $>$ Sn-bearing quartz veins from Filharoso and Carvalhal, respectively. (d). Part of a heterogeneous wolframite crystal from the $\mathrm{W}>$ Sn-bearing quartz veins from Vale das Gatas.

Crystals of cassiterite from the $\mathrm{W}>$ Sn-bearing quartz veins have a homogeneous and similar composition in both the darker and lighter zones (Table 1, analyses 6-9), which contain accidental and uniformly distributed inclusions of rutile (Neiva, 1996). Only the cassiterite from Carris contains inclusions of ilmenite. However at Carvalhal, some cassiterite crystals present strongly pleochroic darker zones, which are distinctly richer in $\mathrm{Ti}$ than the lighter zones (Table 1, analyses 10-11). No chemical distinction was found between the two generations of cassiterite from Panasqueira, even though they belong to two distinct paragenetic stages.

The darker zones in cassiterite from the $\mathrm{Sn}>\mathrm{W}$ bearing quartz veins are richer in $\mathrm{Nb}, \mathrm{Ta}$ and $\mathrm{Fe}$ and correspondingly poorer in $\mathrm{Ti}$ than the cassiterite from $\mathrm{W}>$ Sn-bearing quartz veins (Table 1). The lighter zones of cassiterite from the $\mathrm{Sn}>\mathrm{W}$-bearing quartz veins are poorer in $\mathrm{Ti}$ than the lighter and darker zones of cassiterite from the $\mathrm{W}>$ Sn-bearing quartz veins.

The compositions of the darker and lighter zones of cassiterite crystals from $\mathrm{Sn}>\mathrm{W}$ - and $\mathrm{W}>\mathrm{Sn}$-bearing quartz veins are plotted in the $(\mathrm{Nb}, \mathrm{Ta})-(\mathrm{Fe}, \mathrm{Mn})-(\mathrm{Sn}, \mathrm{Ti})$ compositional diagram (Fig. 3). They plot close to the trend defined by the ideal substitution $(\mathrm{Fe}, \mathrm{Mn})^{2+}+2(\mathrm{Nb}$, Ta $)^{5+}$ D3(Sn,Ti) ${ }^{4+}$ (Černý et al., 1985), strongly support- ing this to be the main mechanism responsible for the incorporation of $\mathrm{Fe}, \mathrm{Mn}, \mathrm{Nb}, \mathrm{Ta}$ and $\mathrm{Ti}$ into the studied cassiterite specimens (Neiva, 1996). The extent of the substitution is markedly more restricted in cassiterite from the $\mathrm{W}>\mathrm{Sn}$-bearing quartz veins than in cassiterite from the $\mathrm{Sn}>\mathrm{W}$-bearing quartz veins.

Cassiterite from the $\mathrm{W}>$ Sn-bearing quartz veins that host inclusions of rutile and ilmenite is richer in $\mathrm{Ti}$ than the darker zones of cassiterite from $\mathrm{Sn}>\mathrm{W}$-bearing quartz veins in which columbite and ixiolite are exsolved (Fig. 4).

\section{Compositions of exsolved and included phases}

\subsection{Exsolutions of columbite and ixiolite in cassiterite}

The darker zones of cassiterite from $\mathrm{Sn}>\mathrm{W}$-bearing quartz veins have exsolved ferrocolumbite (Fig. 5a), manganocolumbite and titanian ixiolite with subordinate $\mathrm{W}>$ Sn (Table 2, Fig. 6a, b). Columbite has higher levels of $\mathrm{Nb}$ and $\mathrm{Ta}$, and lower levels of $\mathrm{Sn}, \mathrm{Ti}$ and $\mathrm{W}$ than titanian ixiolite (Neiva, 1996). In general, the exsolved phases display oscillatory zonation (Table 2, analyses 1-4; Fig. 5b), but some are homogeneous (Fig. 5a). However, progressive zoning was also found. 
Table 1

Electron microprobe data on cassiterite in quartz veins from northern and central Portugal

\begin{tabular}{|c|c|c|c|c|c|c|c|c|c|c|c|}
\hline & \multirow{2}{*}{\multicolumn{5}{|c|}{$\begin{array}{l}\text { Sn }>\text { W-bearing quartz veins } \\
\text { Argozelo }\end{array}$}} & \multicolumn{6}{|c|}{$\mathrm{W}>$ Sn-bearing quartz veins } \\
\hline & & & & & & \multirow{3}{*}{$\begin{array}{l}\text { Carris } \\
\text { Lighter, darker } \\
\text { zones } \\
6\end{array}$} & \multirow{3}{*}{$\begin{array}{l}\text { Filharoso } \\
\text { Lighter, darker } \\
\text { zones } \\
7\end{array}$} & \multirow{3}{*}{$\begin{array}{l}\text { Vale das Gatas } \\
\text { Lighter, darker } \\
\text { zones } \\
8 \\
\end{array}$} & \multirow{3}{*}{$\begin{array}{l}\text { Panasqueira } \\
\begin{array}{l}\text { Lighter, darker } \\
\text { zones }\end{array} \\
9\end{array}$} & \multicolumn{2}{|c|}{ Carvalhal } \\
\hline & \multicolumn{3}{|c|}{ Darker zone } & \multirow{2}{*}{$\begin{array}{l}\text { Lighter } \\
\text { zone } \\
4\end{array}$} & \multirow{2}{*}{$\begin{array}{l}\text { Darker } \\
\text { zone }\end{array}$} & & & & & $\begin{array}{l}\text { Darker } \\
\text { zone }\end{array}$ & $\begin{array}{l}\text { Lighter } \\
\text { zone }\end{array}$ \\
\hline & 1 & 2 & 3 & & & & & & & 10 & 11 \\
\hline $\mathrm{Nb}_{2} \mathrm{O}_{5}$ & 0.35 & 0.58 & 0.50 & 0.05 & 1.12 & - & 0.07 & 0.01 & 0.01 & - & 0.02 \\
\hline $\mathrm{Ta}_{2} \mathrm{O}_{5}$ & 1.47 & 1.95 & 2.15 & 0.23 & 2.37 & - & 0.28 & - & 0.01 & - & - \\
\hline $\mathrm{TiO}_{2}$ & 0.45 & 0.42 & 0.41 & 0.24 & 0.23 & 0.52 & 0.54 & 0.57 & 0.54 & 0.76 & 0.54 \\
\hline $\mathrm{SnO}_{2}$ & 97.37 & 96.30 & 96.10 & 99.46 & 95.50 & 99.48 & 98.98 & 99.29 & 99.54 & 98.90 & 99.10 \\
\hline $\mathrm{WO}_{3}$ & - & - & - & - & - & 0.34 & 0.05 & - & 0.17 & 0.12 & 0.04 \\
\hline $\mathrm{MnO}$ & 0.07 & 0.05 & - & 0.01 & 0.08 & - & - & 0.08 & - & 0.03 & - \\
\hline $\mathrm{FeO}$ & 0.35 & 0.78 & 0.82 & 0.11 & 0.89 & 0.02 & 0.09 & 0.04 & 0.06 & 0.02 & - \\
\hline Total & 100.06 & 100.08 & 99.98 & 100.10 & 100.19 & 100.36 & 100.01 & 99.99 & 100.33 & 99.83 & 99.70 \\
\hline $\mathrm{Nb}$ & 0.004 & 0.007 & 0.006 & - & 0.013 & - & 0.001 & - & - & - & - \\
\hline Ta & 0.010 & 0.013 & 0.015 & 0.002 & 0.016 & - & 0.002 & - & - & - & - \\
\hline $\mathrm{Ti}$ & 0.008 & 0.008 & 0.008 & 0.005 & 0.004 & 0.010 & 0.010 & 0.011 & 0.010 & 0.014 & 0.010 \\
\hline $\mathrm{Sn}$ & 0.970 & 0.959 & 0.958 & 0.992 & 0.950 & 0.987 & 0.985 & 0.988 & 0.988 & 0.984 & 0.980 \\
\hline W & - & - & - & - & - & 0.002 & - & - & 0.001 & 0.001 & - \\
\hline $\mathrm{Mn}$ & 0.001 & 0.001 & - & - & 0.002 & - & - & 0.002 & - & 0.001 & - \\
\hline $\mathrm{Fe}$ & 0.007 & 0.016 & 0.017 & 0.002 & 0.019 & - & 0.002 & 0.001 & 0.001 & - & - \\
\hline Total & 1.000 & 1.004 & 1.004 & 1.001 & 1.004 & 0.999 & 1.000 & 1.002 & 1.000 & 1.001 & 0.999 \\
\hline
\end{tabular}

1, 2, 3 reddish brown zone with increasing distance from exsolved ferrocolumbite. 5 the richest darker zone in $\mathrm{Nb}_{2} \mathrm{O}_{5} .6,7,8,9$ lighter and darker zones of similar composition. 7 Cassiterites from Soutelinho, S. Domingos, Folgar and Bouço present a similar composition to that of Filharoso. below detection limit. Oxides in wt.\%. Cation formula based on two atoms of oxygen. Analyst: A. Neiva.

Some single blebs of ferrocolumbite show an increase in $\mathrm{Nb}$ and $\mathrm{Mn}$ and a decrease in $\mathrm{Ta}$ and $\mathrm{Ta} /(\mathrm{Ta}+\mathrm{Nb})$ from core to rim (Table 2). Some single blebs of ixiolite exhibit an increase in $\mathrm{Nb}, \mathrm{Fe}$ and a decrease in $\mathrm{Ta}, \mathrm{Ta} /$ $(\mathrm{Ta}+\mathrm{Nb})$, Ti and $\mathrm{W}$ from core to rim (Table 2). These changes may be attributed to crystallisation as the temperature decreased.
The alignment of the columbite compositions along the $(\mathrm{Sn}, \mathrm{Ti}, \mathrm{W})-(\mathrm{Fe}, \mathrm{Mn})(\mathrm{Nb}, \mathrm{Ta})_{2}$ join on Fig. 6a suggests that the $(\mathrm{Fe}, \mathrm{Mn})^{2+}+2(\mathrm{Nb}, \mathrm{Ta})^{5+} \mathrm{D} 3(\mathrm{Sn}, \mathrm{Ti})^{4+}$ substitution mechanism is dominant. Titanian ixiolite with subordinate $\mathrm{W}>\mathrm{Sn}$ plots between the $(\mathrm{Sn}, \mathrm{Ti}, \mathrm{W})-(\mathrm{Fe}, \mathrm{Mn})(\mathrm{Nb}$, $\mathrm{Ta})_{2}$ and $(\mathrm{Fe}, \mathrm{Mn})(\mathrm{Nb}, \mathrm{Ta})_{2}-(\mathrm{Fe}, \mathrm{Mn})(\mathrm{Sn}, \mathrm{W}, \mathrm{Ti})$ joins and 'below' the data for columbite on Fig. 6 a.

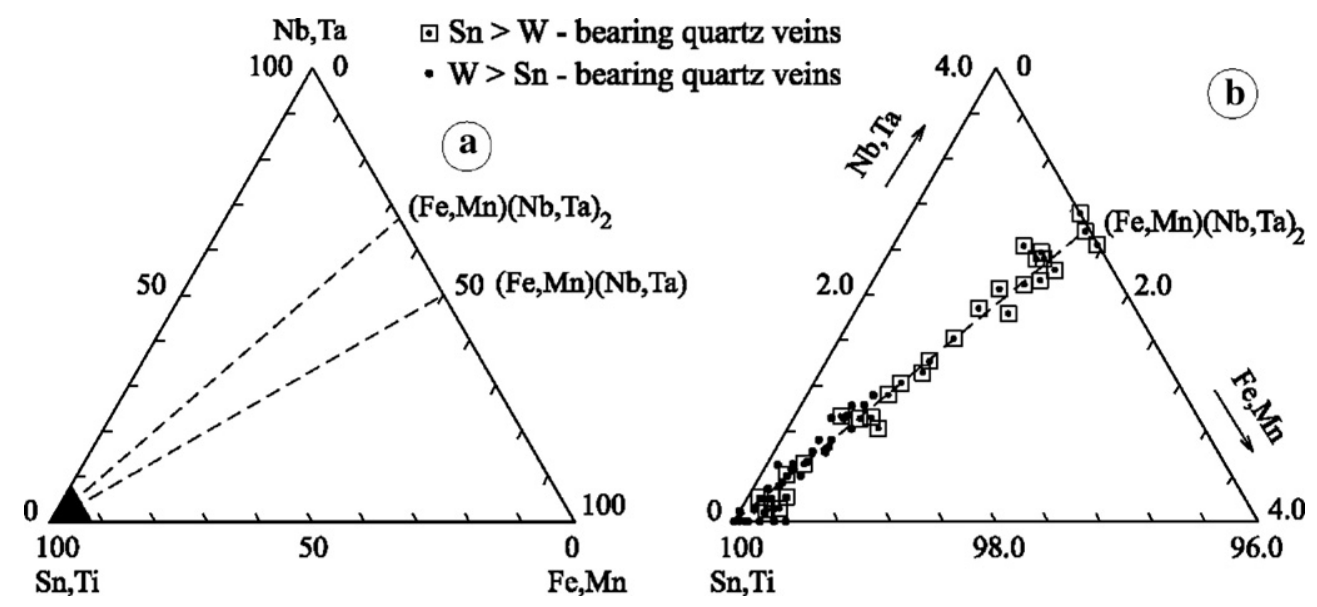

Fig. 3. Composition diagram plotted in terms of $(\mathrm{Na}, \mathrm{Ta})-(\mathrm{Fe}, \mathrm{Mn})-(\mathrm{Sn}, \mathrm{Ti})$ for cassiterite from the $\mathrm{Sn}>\mathrm{W}$ and $\mathrm{W}>\mathrm{Sn}-\mathrm{bearing}$ quartz veins. Diagram (a) shows the full triangular plot, (b) shows an expansion of the $(\mathrm{Sn}+\mathrm{Ti})$ corner. 

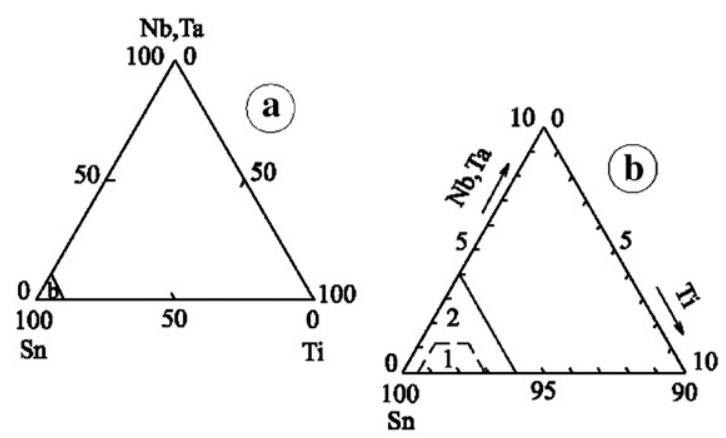

๑ $\mathrm{Sn}>\mathrm{W}$ - bearing quartz veins

- $\mathrm{W}>\mathrm{Sn}$ - bearing quartz veins

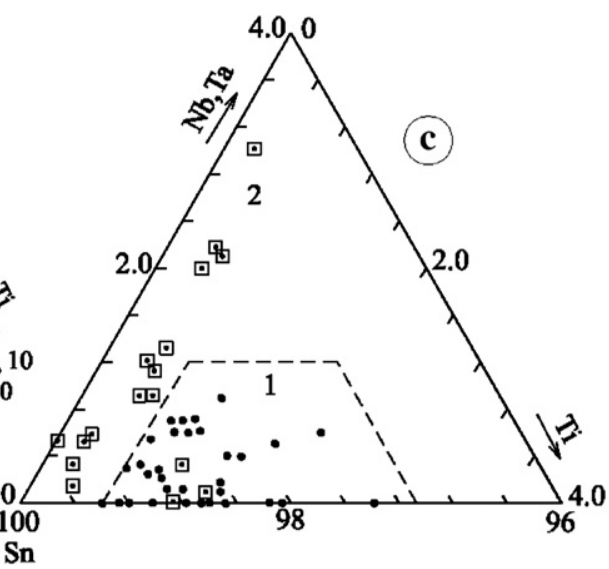

Fig. 4. Compositional diagram plotted in terms of (Nb,Ta)-Ti-Sn diagram for cassiterite from the $\mathrm{Sn}>\mathrm{W}$ and $\mathrm{W}>\mathrm{Sn}$-bearing quartz veins. Diagram (a) shows the full triangular plot, (b) and (c) are progressive enlargements of the Sn corner. Note that cassiterite from $\mathrm{W}>\mathrm{Sn}$-bearing quartz veins hosting rutile \pm ilmenite inclusions fall within a specific area (1), whereas cassiterite from $\mathrm{Sn}>\mathrm{W}$-bearing quartz veins hosting columbite and ixiolite exsolution products plots within a specific area (2).

\subsection{Inclusions of rutile in cassiterite}

The rutile inclusions found in cassiterite from $\mathrm{W}>\mathrm{Sn}-$ bearing quartz veins were analyzed and show $\mathrm{Nb}$ contents that exceed those of Ta (Table 2). They are mostly irregularly zoned (Fig. 5c), but homogeneous crystals also exist (Fig. 5d). In general, Sn predominates over $\mathrm{W}$ in rutile, but $\mathrm{W}>\mathrm{Sn}$ is noted in rutile from both Vale das Gatas and Panasqueira (Table 2). On the compositional diagram (Fig. 6c), rutile compositions cluster between the $(\mathrm{Sn}, \mathrm{Ti}, \mathrm{W})-(\mathrm{Fe}, \mathrm{Mn})(\mathrm{Nb}, \mathrm{Ta})_{2}$ and $(\mathrm{Sn}, \mathrm{Ti}, \mathrm{W})-(\mathrm{Fe}, \mathrm{Mn})$ $(\mathrm{Nb}, \mathrm{Ta})$ joins, suggesting that they probably contain $\mathrm{Fe}^{3+}$. This is also borne out by the fact that the cation totals normalized to two oxygen atoms exceed the ideal value of 1.00. The mechanism: $2(\mathrm{Nb}, \mathrm{Ta})^{5+}(\mathrm{Fe}, \mathrm{Mn})^{2+} \mathrm{D} 3 \mathrm{Ti}^{4+}$ is probably responsible for the incorporation of $\mathrm{Nb}, \mathrm{Ta}$, $\mathrm{Fe}^{2+}$ and $\mathrm{Mn}$ in rutile (Neiva, 1996), but the presence of an additional $\mathrm{Fe}^{3+}(\mathrm{Nb}, \mathrm{Ta}) \mathrm{O}_{4}$ component causes some deviation from this simple substitution.

Ilmenite inclusions were only found in the cassiterite of $\mathrm{W}>$ Sn-bearing quartz veins from Carris. Some are homogeneous (Table 2), whereas others are irregularly zoned (Fig. 5d). Ilmenite has a very low $\mathrm{Nb}$ content.

\section{Wolframite compositions}

In the majority of the deposits, wolframite compositions have a dominant hübnerite component, whereas wolframite from Panasqueira has a dominant ferberite component (Tables 3 and 4). The microanalytical dataset shows the following features. (a) At Filharoso, Soutelinho, S. Domingos, Bouço, Folgar, Carvalhal and Panasqueira (Table 3), in individual crystals from the same deposit, differences in composition commonly range between 1 and $7 \mathrm{~mol} \%$ hübnerite and there is uniformity of composition within each deposit, suggesting that the fluids are relatively homogeneous in composition in the main silicate-oxide stage. (b) At Filharoso and Panasqueira, a few crystals are heterogeneous, showing inner patches richer in Mn than the rest of the crystal (Table 3, analyses 1-2, 6-7). (c) At Argozelo, some crystals are heterogeneous (Fig. 5e, f) and others show complex oscillatory zoning (Table 3, analyses 10-13); at Vale das Gatas, some also show this zoning (Table 4, analyses 14-17). (d) Other zoned crystals show a decrease in the hübnerite component from core to rim at Vale das Gatas (Table 4, analyses 18-19), as there is more than one generation of wolframite in this ore deposit. In general, backscattered images do not reveal any zoning in wolframite, although this can be observed microscopically in transmitted light and proven by spot analysis, because the mean atomic weight is similar in different zones of wolframite crystals.

Two hundred and eighty electron probe microanalyses were obtained from 28 crystals of wolframite from Panasqueira. Major element chemistry shows a hübnerite component ranging from 13 to $23 \mathrm{~mol} \%$ (Table 3 and analyses 6-9), agreeing with the data of Saraiva (1971) who studied $>100$ wolframite samples and determined $\mathrm{Fe}$ and $\mathrm{Mn}$ by classical wet chemical methods. This range is also similar to the 12 to $20 \mathrm{~mol} \%$ hübnerite range given by Polya (1988) as the average chemical composition of 41 wolframite crystals analyzed by electron microprobe. Collectively, the data suggest that the main stage ore-forming fluids are relatively uniform in composition. Most single crystals are homogeneous and the difference in composition within each crystal is generally 

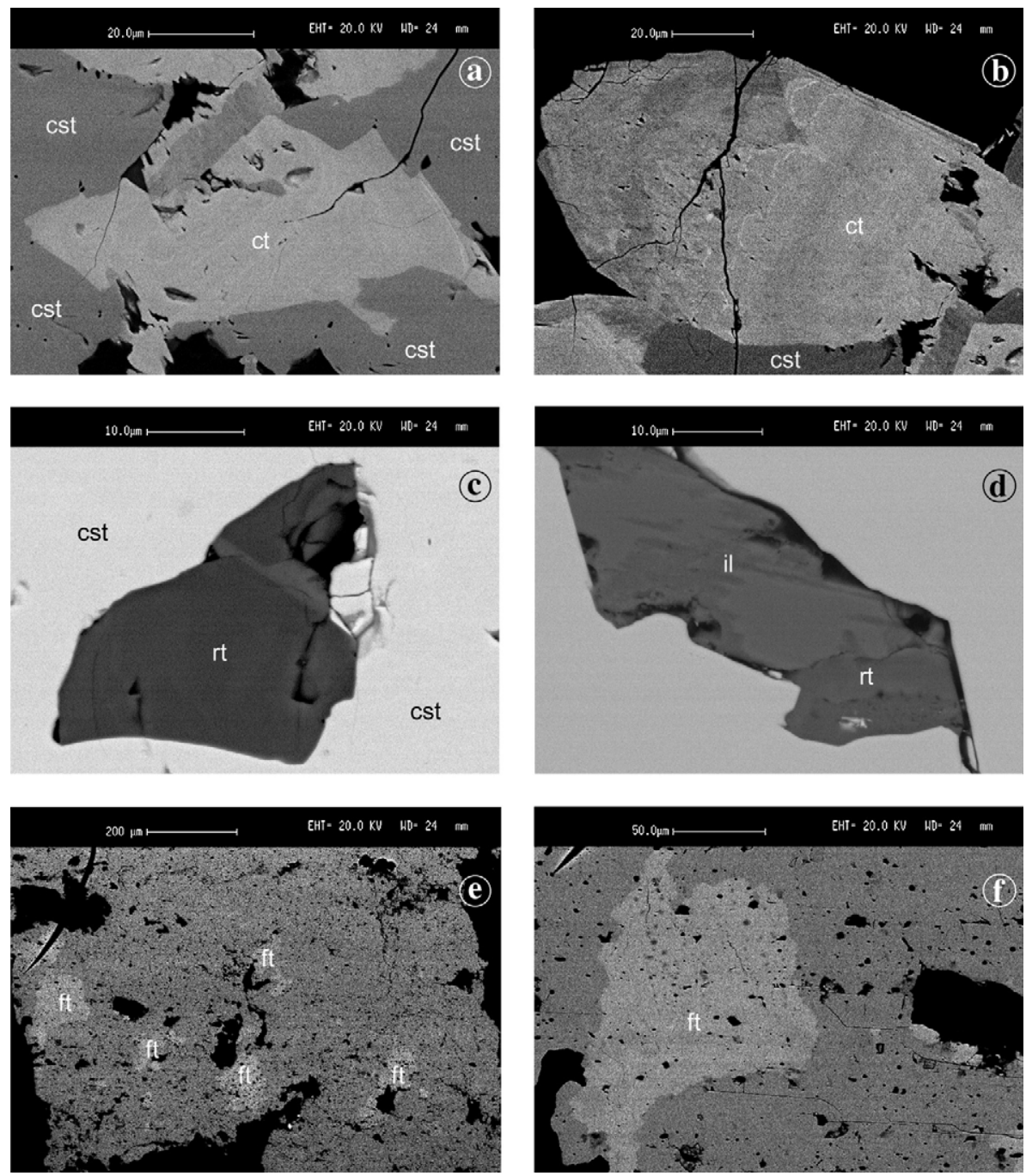

Fig. 5. Backscattered electron images. (a) Homogeneous exsolved ferrocolumbite (ct) within cassiterite (cst) from Sn $>$ W-bearing quartz veins in the Argozelo deposit; (b) oscillatory zoned exsolved ferrocolumbite (ct) from within the darker zones of cassiterite (cst) in Sn $>$ W-bearing quartz veins from the Argozelo deposit; (c) irregularly zoned rutile (rt) inclusion in cassiterite from $\mathrm{W}>$ Sn-bearing quartz veins in the Carris deposit; (d) homogeneous inclusion of rutile (rt) and irregularly zoned ilmenite (il) inclusion in cassiterite from W $>$ Sn-bearing quartz veins in the Carris deposit. (e) and (f). Heterogeneous wolframite from the Argozelo deposit; the brighter areas (marked 'ft') have a higher ferberite component.

less than $2 \mathrm{~mol} \%$ hübnerite; much of this might be attributed to analytical error. However, some patchy heterogeneous samples were also found from point analyses (Table 3, analyses 6-7). The greatest compositional difference between the aberrant patches and the common crystal is up to 9 mol\% hübnerite, which is nevertheless much lower than the $20 \mathrm{~mol} \%$ hübnerite range indicated by Polya (1988). In the present study of specimens from Panasqueira, the wolframites do not show the significant enrichment in $\mathrm{Nb}$ adjacent to major fault zones, as was described by Polya (1988).

At Argozelo, the complex oscillatory zoned wolframite has a wide range of composition from 33 to $67 \mathrm{~mol} \%$ hübnerite (Table 3, analyses 10-13).
Two hundred and ten electron microprobe analyses were obtained from 30 crystals of wolframite from Vale das Gatas. The heterogeneous crystals (Fig. 2d) and the complex oscillatory zoned crystals containing 89 to $96 \mathrm{~mol} \%$ hübnerite identified by spot analyses (Table 4 , analyses 14-17) are interpreted to correspond to wolframite precipitation in the first stage (Vilela de Matos, in press). The zoned crystals containing a core and a rim with 95 and $54 \mathrm{~mol} \%$ hübnerite, respectively (Table 4, analyses 18 and 19), correspond to two generations of wolframite. This is supported by the well-defined contact between core and rim, which can be seen microscopically. A similar composition to that of the rim is found close to fractures, making some crystals heterogeneous. The core 
Table 2

Electron microprobe data of products of exsolution from cassiterite of $\mathrm{Sn}>\mathrm{W}$-bearing quartz veins and inclusions in cassiterite of W $>$ Sn-bearing quartz veins in northern and central Portugal

\begin{tabular}{|c|c|c|c|c|c|c|c|c|c|c|c|c|c|}
\hline & \multicolumn{9}{|c|}{ Argozelo } & \multirow{3}{*}{\multicolumn{2}{|c|}{$\begin{array}{l}\text { Carvalhal Vale das Gatas } \\
\text { Inclusions of } \\
\text { Rutile }\end{array}$}} & \multirow{3}{*}{ Panasqueira } & \multirow{4}{*}{$\begin{array}{l}\text { Carris } \\
\frac{\text { Ilmer }}{13}\end{array}$} \\
\hline & \multicolumn{6}{|c|}{ Exsolved ferrocolumbite } & \multirow{3}{*}{$\begin{array}{l}\text { Exsolved } \\
\text { manganoco } \\
\text { lumbite } \\
7\end{array}$} & \multicolumn{2}{|c|}{$\begin{array}{l}\text { Exsolved } \\
\text { ixiolite }\end{array}$} & & & & \\
\hline & \multicolumn{4}{|c|}{ Core $\longrightarrow$ Rim } & \multirow{2}{*}{$\frac{\text { Core }}{5}$} & \multirow{2}{*}{$\frac{\operatorname{Rim}}{6}$} & & \multirow{2}{*}{$\frac{\text { Core }}{8}$} & \multirow{2}{*}{$\frac{\operatorname{Rim}}{9}$} & & & & \\
\hline & 1 & 2 & 3 & 4 & & & & & & 10 & 11 & 12 & \\
\hline $\mathrm{Nb}_{2} \mathrm{O}_{5}$ & 45.02 & 58.17 & 54.30 & 47.51 & 48.27 & 55.86 & 64.47 & 64.21 & 70.96 & 2.38 & 5.42 & 0.59 & \\
\hline $\mathrm{Ta}_{2} \mathrm{O}_{5}$ & 35.45 & 18.77 & 25.43 & 32.76 & 31.03 & 22.06 & 10.51 & 0.60 & 0.43 & 0.90 & 0.18 & - & \\
\hline $\mathrm{TiO}_{2}$ & 0.62 & 2.26 & 0.78 & 1.07 & 1.12 & 1.89 & 3.13 & 5.98 & 2.24 & 93.22 & 87.54 & 92.93 & 5 \\
\hline $\mathrm{SnO}_{2}$ & 0.58 & 1.13 & 0.37 & 0.67 & 0.82 & 0.79 & 1.03 & 0.41 & 0.27 & 1.82 & 0.80 & 1.27 & \\
\hline $\mathrm{WO}_{3}$ & 0.22 & 0.64 & 0.12 & 0.07 & 0.48 & 0.33 & 2.01 & 8.26 & 5.43 & 0.54 & 3.91 & 3.70 & \\
\hline $\mathrm{MnO}$ & 2.69 & 2.45 & 2.48 & 2.34 & 2.56 & 2.77 & 11.30 & 8.21 & 5.83 & - & 0.16 & - & \\
\hline $\mathrm{FeO}$ & 15.20 & 16.39 & 16.11 & 15.28 & 15.46 & 16.39 & 7.93 & 11.92 & 14.66 & 1.29 & 1.41 & 1.10 & 4 \\
\hline Total & 99.78 & 99.81 & 99.53 & 99.70 & 99.74 & 100.09 & 100.38 & 99.59 & 99.82 & 100.15 & 99.42 & 99.59 & 10 \\
\hline $\mathrm{Nb}$ & 1.333 & 1.590 & 1.537 & 1.387 & 1.401 & 1.546 & 1.693 & 2.198 & 2.452 & 0.015 & 0.034 & 0.004 & 0 \\
\hline Тa & 0.632 & 0.309 & 0.433 & 0.575 & 0.541 & 0.367 & 0.166 & 0.013 & 0.009 & 0.003 & 0.001 & - & - \\
\hline $\mathrm{Ti}$ & 0.031 & 0.103 & 0.037 & 0.052 & 0.054 & 0.087 & 0.137 & 0.340 & 0.128 & 0.956 & 0.921 & 0.962 & 2 \\
\hline Sn & 0.015 & 0.027 & 0.009 & 0.017 & 0.021 & 0.019 & 0.024 & 0.012 & 0.008 & 0.010 & 0.004 & 0.007 & 0 \\
\hline W & 0.004 & 0.010 & 0.002 & 0.001 & 0.008 & 0.005 & 0.030 & 0.162 & 0.107 & 0.002 & 0.014 & 0.013 & 0 \\
\hline $\mathrm{Mn}$ & 0.149 & 0.125 & 0.132 & 0.128 & 0.139 & 0.144 & 0.556 & 0.526 & 0.375 & - & 0.002 & - & 0 \\
\hline $\mathrm{Fe}$ & 0.833 & 0.829 & 0.844 & 0.825 & 0.829 & 0.839 & 0.385 & 0.755 & 0.930 & 0.015 & 0.016 & 0.013 & 1 \\
\hline Total & 2.997 & 2.993 & 2.994 & 2.985 & 2.995 & 3.011 & 2.991 & 4.006 & 4.009 & 1.001 & 0.992 & 0.999 & 3 \\
\hline$\frac{100 \mathrm{Mn}}{\mathrm{Mn}+\mathrm{Fe}}$ & 0.15 & 0.13 & 0.14 & 0.13 & 0.14 & 0.15 & 0.59 & 0.41 & 0.29 & & & & \\
\hline$\frac{100 \mathrm{Ta}}{\mathrm{Ta}+\mathrm{Nb}}$ & 0.32 & 0.16 & 0.22 & 0.29 & 0.28 & 0.19 & 0.09 & 0.01 & 0 & & & & \\
\hline
\end{tabular}

1, 2, 3, 4 oscillatory zoned columbite; 5 and 6 regularly zoned columbite; 7 homogeneous manganocolumbite; 8 and 9 regularly zoned titanian ixiolite with $\mathrm{W}>\mathrm{Sn}$; 11 and 12 the richest rutile in $\mathrm{Nb}_{2} \mathrm{O}_{5}$ from the respective deposit. Oxides in wt.\%. - below detection limit. Cation formula based on 6 atoms for oxygen for columbite and ilmenite and 8 and 2 atoms of oxygen for ixiolite and rutile respectively. Analyst: A. Neiva.

composition is probably contemporaneous with the oscillatory zoned crystals. Fluids enriched in Fe subsequently penetrated along fractures and borders of wolframite crystals, reacted with them, and later composi- tions precipitated to give rise to the zoned crystals that show a decrease in $\mathrm{Mn}$ and an increase in Fe from core to rim (Fig. 7a). However, the reactions brought about by the later fluids did not extend to the whole quartz vein, as

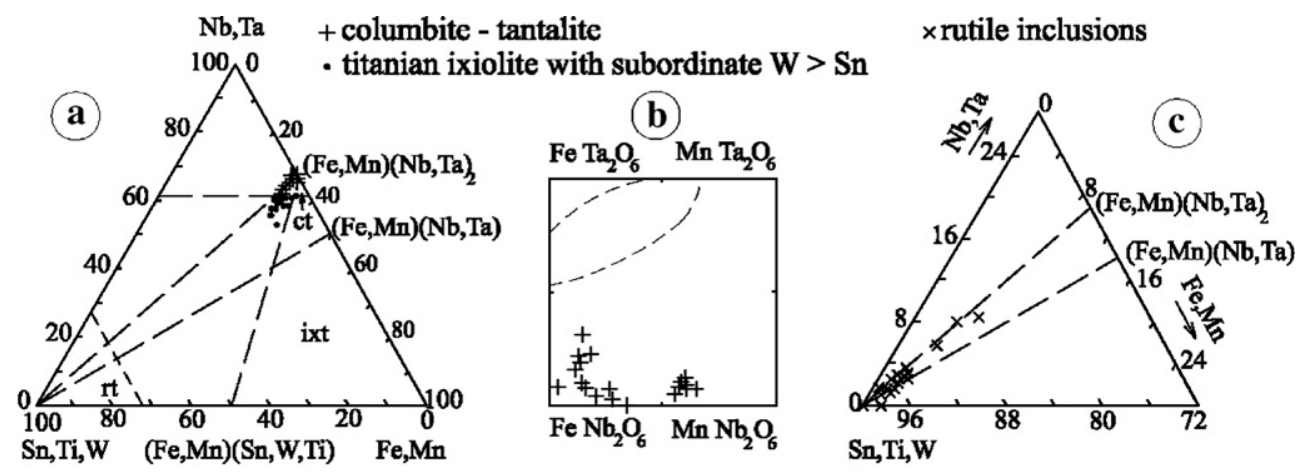

Fig. 6. (a). Compositional diagram plotted in terms of $(\mathrm{Sn}, \mathrm{Ti}, \mathrm{W})-(\mathrm{Nb}, \mathrm{Ta})-(\mathrm{Fe}, \mathrm{Mn})$ in which exsolved columbite (ct), titanian ixiolite with subordinate $\mathrm{W}>\mathrm{Sn}$ (ixt) from cassiterite of $\mathrm{Sn}>\mathrm{W}$-bearing quartz veins have been plotted. (b). Columbite which has exsolved from cassiterite in these quartz veins is plotted in the 'columbite quadrilateral' showing two distinct compositions of ferrocolumbite and manganocolumbite; the miscibility gap (dashed lines) between individual compositions in ferrotapiolite and ferro-tantalite are taken from Černý et al. (1992). (c). Compositional diagram plotted in terms of $(\mathrm{Sn}, \mathrm{Ti}, \mathrm{W})-(\mathrm{Nb}, \mathrm{Ta})-(\mathrm{Fe}, \mathrm{Mn})$ for rutile inclusions in cassiterite from $\mathrm{W}>$ Sn-bearing quartz veins. 
Table 3

Electron microprobe data of wolframite from some quartz veins in northern and central Portugal

\begin{tabular}{|c|c|c|c|c|c|c|c|c|c|c|c|c|c|}
\hline & \multicolumn{9}{|c|}{$\mathrm{W}>$ Sn-bearing quartz veins } & \multirow{2}{*}{\multicolumn{4}{|c|}{$\frac{\mathrm{Sn}>\text { W-bearing quartz veins }}{\text { Argozelo }}$}} \\
\hline & \multicolumn{2}{|c|}{ Filharoso } & \multirow{3}{*}{$\begin{array}{l}\text { S. Domingos Bouço } \\
3\end{array}$} & \multirow{3}{*}{$\begin{array}{l}\text { Folgar } \\
4\end{array}$} & \multirow{3}{*}{$\begin{array}{l}\text { Carvalhal } \\
\overline{5}\end{array}$} & \multicolumn{4}{|c|}{ Panasqueira } & & & & \\
\hline & & & & & & & & Core & Rim & Core - & & $>1$ & im \\
\hline & 1 & 2 & & & & 6 & 7 & 8 & 9 & 10 & 11 & 12 & 13 \\
\hline $\mathrm{TiO}_{2}$ & - & 0.03 & 0.01 & 0.01 & 0.01 & - & 0.02 & 0.11 & - & - & 0.03 & - & - \\
\hline $\mathrm{MnO}$ & 21.07 & 15.40 & 17.07 & 13.83 & 17.21 & 5.34 & 3.41 & 3.59 & 3.13 & 7.86 & 14.29 & 11.46 & 16.24 \\
\hline $\mathrm{FeO}$ & 4.13 & 9.98 & 7.58 & 11.24 & 7.13 & 18.45 & 20.63 & 21.90 & 21.72 & 16.54 & 10.55 & 12.90 & 8.15 \\
\hline $\mathrm{Nb}_{2} \mathrm{O}_{5}$ & 0.22 & 0.23 & 0.09 & 0.20 & 0.25 & 0.38 & 0.26 & 1.88 & 0.47 & 0.30 & 0.94 & 0.85 & 0.48 \\
\hline $\mathrm{SnO}_{2}$ & - & 0.02 & 0.03 & 0.02 & 0.03 & 0.05 & 0.02 & 0.03 & 0.07 & - & 0.06 & 0.02 & 0.06 \\
\hline $\mathrm{Ta}_{2} \mathrm{O}_{5}$ & - & - & 0.03 & 0.03 & 0.02 & - & - & 0.05 & - & 0.21 & 0.12 & 0.16 & 0.07 \\
\hline $\mathrm{WO}_{3}$ & 74.85 & 74.57 & 75.31 & 74.87 & 75.02 & 75.52 & 75.11 & 72.19 & 74.34 & 74.95 & 73.57 & 73.93 & 74.42 \\
\hline Total & 100.07 & 100.23 & 100.12 & 100.20 & 99.67 & 99.74 & 99.45 & 99.75 & 99.73 & 99.86 & 99.56 & 99.32 & 99.42 \\
\hline $\mathrm{Ti}$ & - & 0.001 & - & - & - & - & 0.001 & 0.004 & - & - & 0.001 & - & - \\
\hline $\mathrm{Mn}$ & 0.876 & 0.639 & 0.716 & 0.577 & 0.297 & 0.228 & 0.146 & 0.147 & 0.132 & 0.332 & 0.598 & 0.484 & 0.686 \\
\hline $\mathrm{Fe}^{3+}$ & - & 0.199 & 0.125 & 0.162 & 0.103 & 0.031 & 0.064 & 0.213 & 0.143 & 0.098 & 0.163 & 0.113 & 0.118 \\
\hline $\mathrm{Fe}^{2+}$ & 0.170 & 0.210 & 0.189 & 0.300 & 0.624 & 0.746 & 0.804 & 0.680 & 0.757 & 0.592 & 0.273 & 0.426 & 0.222 \\
\hline $\mathrm{Nb}$ & 0.005 & 0.005 & 0.002 & 0.005 & 0.005 & 0.009 & 0.006 & 0.042 & 0.011 & 0.007 & 0.021 & 0.019 & 0.011 \\
\hline $\mathrm{Sn}$ & - & - & 0.001 & - & 0.001 & 0.001 & - & 0.001 & 0.002 & - & 0.001 & - & 0.001 \\
\hline $\mathrm{Ta}$ & - & - & 0.001 & 0.001 & - & - & - & 0.001 & - & 0.003 & 0.002 & 0.002 & 0.001 \\
\hline $\mathrm{W}$ & 0.949 & 0.946 & 0.966 & 0.955 & 0.970 & 0.985 & 0.979 & 0.912 & 0.955 & 0.968 & 0.941 & 0.956 & 0.961 \\
\hline Total & 2.000 & 2.000 & 2.000 & 2.000 & 2.000 & 2.000 & 2.000 & 2.000 & 2.000 & 2.000 & 2.000 & 2.000 & 2.000 \\
\hline $\mathrm{mol}^{2} \mathrm{MnWO}_{4}$ & 83.8 & 61.0 & 69.5 & 55.5 & 71.0 & 22.7 & 14.3 & 14.2 & 12.7 & 32.5 & 57.8 & 47.3 & 66.9 \\
\hline
\end{tabular}

1 Inner patch; Soutelinho wolframite is similar to $1 ; 6$ and 7 single crystal; 6 inner patch; 8 and 9 single zoned crystal for $\mathrm{Nb}$ and $\mathrm{W} ; 10,11,12$ and 13 complex oscillatory single zoned crystal. Oxides in wt.\%. - below detection limit. Cation formula are calculated on the basis of 4 atoms of oxygen. $\mathrm{Fe}^{3+}$ is calculated on the basis of charge balance and 2 cations. Analyst: A. Neiva.

Table 4

Electron microprobe data of wolframite from other $\mathrm{W}>$ Sn-bearing quartz veins in northern Portugal

\begin{tabular}{|c|c|c|c|c|c|c|c|c|c|}
\hline & \multicolumn{7}{|c|}{ Vale das Gatas } & \multicolumn{2}{|l|}{ Carris } \\
\hline & \multicolumn{3}{|l|}{ Core } & \multirow{2}{*}{$\frac{\text { Rim }}{17}$} & \multirow{2}{*}{$\frac{\text { Core }}{18}$} & \multirow{2}{*}{$\frac{\operatorname{Rim}}{19}$} & \multirow[b]{2}{*}{20} & \multirow[b]{2}{*}{21} & \multirow[b]{2}{*}{22} \\
\hline & 14 & 15 & 16 & & & & & & \\
\hline $\mathrm{TiO}_{2}$ & 0.02 & 0.04 & 0.04 & - & - & - & 0.01 & 0.02 & 0.02 \\
\hline $\mathrm{MnO}$ & 21.85 & 22.62 & 21.86 & 22.56 & 22.06 & 12.66 & 4.28 & 21.68 & 6.45 \\
\hline $\mathrm{FeO}$ & 2.68 & 2.06 & 2.53 & 0.90 & 1.27 & 10.93 & 20.09 & 2.24 & 17.81 \\
\hline $\mathrm{Nb}_{2} \mathrm{O}_{5}$ & 0.02 & - & 0.04 & 0.09 & 0.08 & 0.02 & 0.63 & 0.07 & 0.01 \\
\hline $\mathrm{SnO}_{2}$ & 0.06 & - & 0.08 & - & - & - & - & - & - \\
\hline $\mathrm{Ta}_{2} \mathrm{O}_{5}$ & 0.05 & 0.04 & - & - & - & - & - & - & 0.02 \\
\hline $\mathrm{WO}_{3}$ & 75.33 & 75.34 & 75.46 & 76.03 & 76.22 & 76.06 & 74.61 & 76.15 & 75.48 \\
\hline Total & 100.01 & 100.10 & 100.01 & 99.58 & 99.63 & 99.67 & 99.62 & 100.16 & 99.79 \\
\hline $\mathrm{Ti}$ & 0.001 & 0.002 & 0.002 & - & - & - & - & 0.001 & 0.001 \\
\hline $\mathrm{Mn}$ & 0.918 & 0.946 & 0.920 & 0.965 & 0.945 & 0.542 & 0.181 & 0.917 & 0.273 \\
\hline $\mathrm{Fe}^{3+}$ & 0.111 & 0.086 & 0.105 & 0.014 & - & 0.017 & 0.095 & 0.048 & 0.078 \\
\hline $\mathrm{Fe}^{2+}$ & - & - & - & 0.024 & 0.054 & 0.445 & 0.744 & 0.046 & 0.668 \\
\hline $\mathrm{Nb}$ & - & - & 0.001 & 0.002 & 0.002 & 0.001 & 0.015 & 0.002 & - \\
\hline $\mathrm{Sn}$ & 0.001 & - & 0.001 & - & - & - & - & - & - \\
\hline $\mathrm{Ta}$ & 0.001 & 0.001 & - & - & - & - & - & - & - \\
\hline W & 0.968 & 0.965 & 0.971 & 0.995 & 0.999 & 0.995 & 0.965 & 0.986 & 0.980 \\
\hline Total & 2.000 & 2.000 & 2.000 & 2.000 & 2.000 & 2.000 & 2.000 & 2.000 & 2.000 \\
\hline $\mathrm{mol}_{0} \mathrm{MnWO}_{4}$ & 89.2 & 91.7 & 89.8 & 96.2 & 94.6 & 54.0 & 17.7 & 90.7 & 26.8 \\
\hline
\end{tabular}

$14,15,16$ and 17 complex oscillatory zoned single crystal; 18 and 19 another zoned crystal; 20 the youngest generation and the richest in $\mathrm{Nb}_{2} \mathrm{O}_{5}$ from Vale das Gatas. 21 Without inclusions; 22 with scheelite inclusions. Oxides in wt.\%; - below detection limit. Cation formula are calculated on the basis of 4 atoms of oxygen. $\mathrm{Fe}^{3+}$ is calculated on the basis of charge balance and 2 cations. Analyst: A. Neiva. 
oscillatory zoned crystals are preserved. The youngest generation of wolframite, with $18 \mathrm{~mol} \%$ hübnerite, which occurs in single homogeneous crystals, is the richest in $\mathrm{Nb}$ (Table 4, analysis 20) and belongs to the second hypogene stage as it is associated with sulphides, which mainly precipitated in this stage (Vilela de Matos, in press). This suggests that a drop in ore-forming temperature favoured enrichment of the fluids in $\mathrm{Nb}$. The compositional range (18 to $96 \mathrm{~mol} \%$ hübnerite) is in accordance with that of 15 to $91 \mathrm{~mol} \%$ given by Vilela de Matos (in press) and Vilela de Matos and Sousa (1994), but the significant $\mathrm{Nb}$ contents were determined only by the present study (Table 4). Wolframite crystals from quartz veins crosscutting granite have similar compositions to those of wolframite from quartz veins that crosscut schist.

At Carris, two distinct generations of wolframite were found in independent homogeneous crystals. In general, scheelite is later than wolframite. The later wolframite contains scheelite inclusions, whereas the earlier wolframite does not have any inclusions. The later generation is richer in $\mathrm{Fe}$ and poorer in $\mathrm{Mn}$ than the earlier generation (Table 4, analyses 21-22). Elsewhere in Portugal, wolframite pseudomorphs replacing scheelite contain $89 \mathrm{~mol} \% \mathrm{WO}_{4} \mathrm{Fe}$ (Cotelo Neiva et al., 1956).
Niobium is the only minor element determined by electron microprobe which appears to be concentrated in wolframite from Argozelo, Panasqueira and Vale das Gatas (Tables 3 and 4). The abundance of $\mathrm{Nb}$ is negatively correlated with W (Fig. 7b, c) and does not depend on the hübnerite content (Tables 3 and 4). Electron microprobe analyses revealed compositional zoning expressed in varying $\mathrm{Nb}$ and $\mathrm{W}$ contents in only three single wolframite crystals from Panasqueira (Fig. 7d, e). In such cases, the rim is richer in $\mathrm{W}$ and poorer in $\mathrm{Nb}$ than the core (Table 3, analyses $8-9$ ). The crystals of wolframite analyzed contain neither inclusions nor exsolution products of $\mathrm{Nb}$-bearing oxide minerals.

Niobium enters wolframite in solid solution and is probably incorporated into the wolframite lattice by means of the coupled substitution $\left(\mathrm{Fe}^{2+}, \mathrm{W}^{6+}\right) \mathrm{D}\left(\mathrm{Fe}^{3+}\right.$, $\mathrm{Nb}^{5+}$ ), because the $\mathrm{Nb}$-rich wolframite has greater unit cell parameters than those in Nb-poor wolframite of similar major element composition (Polya, 1988). The $\mathrm{Fe}^{3+}$ content of the wolframite analysed by electron microprobe was not independently measured in this study. However, $\mathrm{Fe}^{3+}$ and $\mathrm{Fe}^{2+}$ were calculated on the basis of a charge balance of 2 cations. A strong negative correlation between $\left(\mathrm{W}^{6+}+\mathrm{Fe}_{\text {calc }}^{2+}\right)$ and $\left(\mathrm{Nb}^{5+}+\mathrm{Fe}_{\text {calc }}^{3+}\right)$ was found for
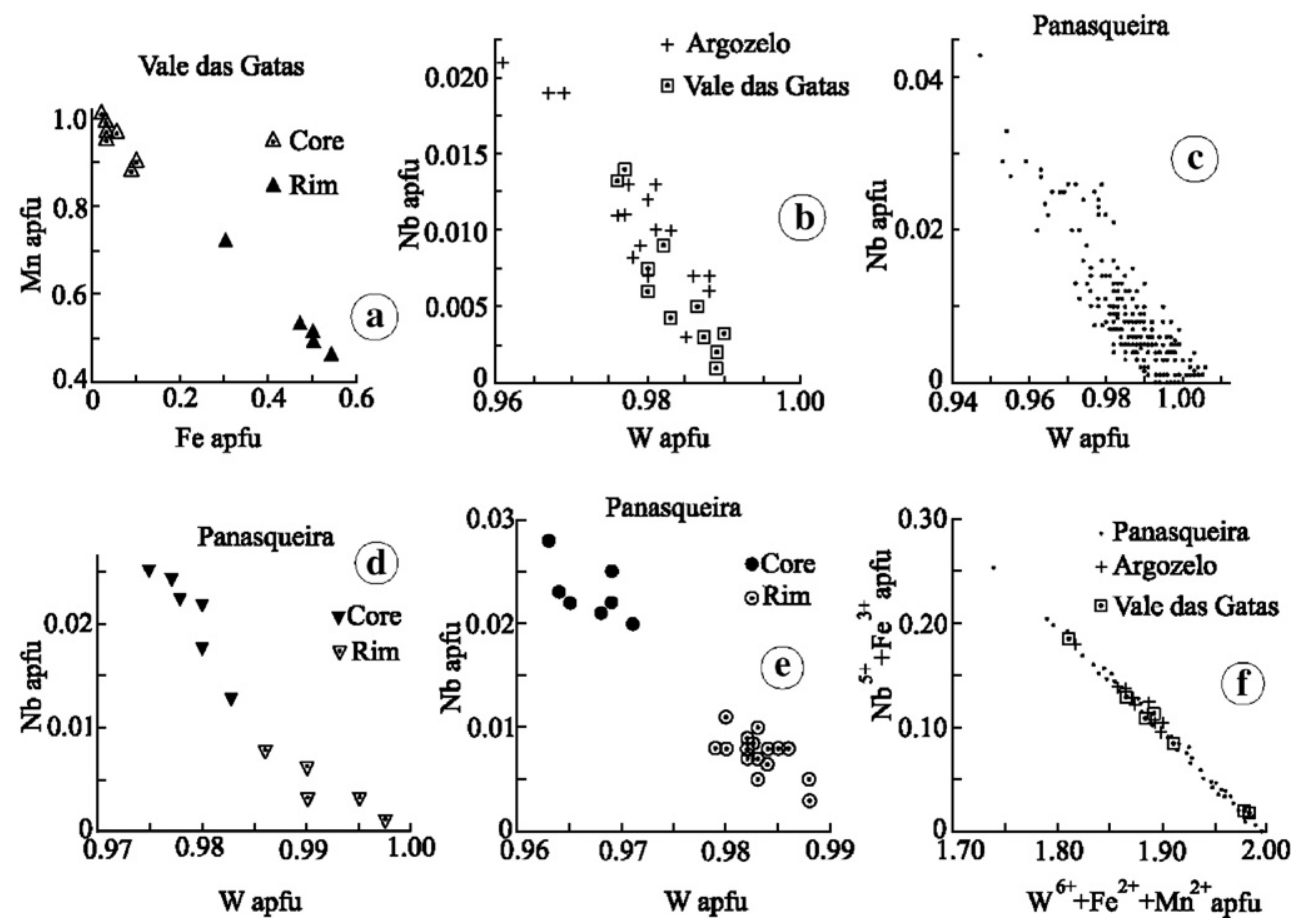

Fig. 7. Compositional plots for wolframites from northern and central Portugal. (a). Mn vs. Fe within a zoned single crystal from Vale das Gatas. (b) and (c). Nb vs. W contents in individual analyses from several crystals from Argozelo, Vale das Gatas and Panasqueira. (d) and (e). Nb vs. W in two different single zoned crystals. (f). Plot of $\left(\mathrm{Nb}^{5+}+\mathrm{Fe}_{\text {calc }}^{3+}\right)$ versus $\left(\mathrm{W}^{6+}+\mathrm{Fe}_{\text {calc }}^{2+}+\mathrm{Mn}^{2+}\right)$ for wolframite crystals containing $\mathrm{Nb}$. 
wolframite compositions from Panasqueira, which contain a dominant ferberite component, but the inner patch is the richest in $\mathrm{Mn}$ and plots outside this trend. Therefore, the coupled $\left[(\mathrm{Fe}, \mathrm{Mn})^{2+}, \mathrm{W}^{6+}\right] \mathrm{D}\left(\mathrm{Fe}^{3+}, \mathrm{Nb}^{5+}\right)$ substitution probably takes place as supported by the correlation between $\left(\mathrm{W}^{6+}+\mathrm{Fe}_{\text {calc }}^{2+}+\mathrm{Mn}^{2+}\right)$ and $\left(\mathrm{Nb}^{5+}+\mathrm{Fe}_{\text {calc }}^{3+}\right)$ (Fig. $\left.7 \mathrm{f}\right)$. The Ta content is very low (Tables 3 and 4); the element probably joins $\mathrm{Nb}$ in the coupled substitution.

Some wolframite analyses from Panasqueira have the highest calculated $\mathrm{Fe}^{3+}$ values (Table 3), suggesting that they precipitated from oxidized fluids. The oxygen and hydrogen isotopic compositions of the fluids from the main oxide-silicate stage lie in the range $\delta^{18} \mathrm{O}=3-7 \%$ o and $\delta \mathrm{D}=-80$ to $-30 \%$ and represent mixtures of meteoric and magmatic waters (Kelly and Rye, 1979; Bussink et al., 1984). They either result from the isotopic exchange of $-54 \%$ o $\mathrm{D}$ meteoric water with granitic rocks at about $375^{\circ} \mathrm{C}$, with the meteoric-dominated oreforming fluids having previously reacted with the Beira schists (Polya, 1989; Polya et al., 2000), or correspond to a mixture of a magmatic component, resulting from mantle-derived fluids (Burnard and Polya, 2004), and meteoric water (e.g., Polya et al., 2000).

\section{Discussion}

In general, the study has identified only one generation of cassiterite. The two generations of cassiterite in the $\mathrm{W}>$ Sn-bearing quartz veins from Panasqueira do not show any compositional differences. Cassiterites from $\mathrm{Sn}>\mathrm{W}$ - and $\mathrm{W}>$ Sn-bearing quartz veins are zoned (Fig. $2 \mathrm{a}-\mathrm{c}$ ). In the $\mathrm{Sn}>\mathrm{W}$-bearing quartz veins, the zones which appear lighter in transmitted light are homogeneous and have a nearly pure $\mathrm{SnO}_{2}$ composition. The darker zones are richer in $\mathrm{Nb}, \mathrm{Ta}$ and $\mathrm{Fe}$ (Table 1), display oscillatory zonation and show exsolution of ferrocolumbite (Fig. 5a, b), manganocolumbite and titanian ixiolite with $\mathrm{W}>\mathrm{Sn}$ (Table 2). In these veins, columbite and ixiolite precipitated earlier than cassiterite and its products of exsolution. All these minerals belong to the early muscovite selvage formation stage of mineralization. In the $\mathrm{W}>$ Sn-bearing quartz veins, the lighter and darker zones of cassiterite have similar compositions (Table 1) and contain inclusions of rutile (Fig. 5c, d; Table 2) and, rarely, of ilmenite (Fig. 5d; Table 2). This is consistent with the occurrence of earlier rutile and ilmenite, rather than cassiterite. The rutile and ilmenite belong to the early muscovite selvage formation stage of mineralization, whereas cassiterite belongs to the main silicate-oxide stage.

Furthermore, the darker zones of cassiterite from $\mathrm{Sn}>\mathrm{W}$-bearing quartz veins have higher $\mathrm{Nb}$, Ta and $\mathrm{Fe}$ contents and a lower Ti content than the darker and lighter zones of cassiterite from $\mathrm{W}>$ Sn-bearing quartz veins (Table 1). This is supported by the fact that the darker zones of cassiterite from Portuguese granitic pegmatites and Sn-bearing quartz veins are richer in $\mathrm{Nb}$, $\mathrm{Ta}$ and $\mathrm{Fe}$ and poorer in $\mathrm{Ti}$ than the darker and lighter zones of cassiterite from $\mathrm{W}>$ Sn-bearing quartz veins (Neiva, 1996). The lighter zones of cassiterite from the $\mathrm{Sn}>\mathrm{W}$-bearing quartz veins are poorer in Ti than both the lighter and darker zones of cassiterite from the latter veins. Therefore, cassiterites from the two vein types have distinct compositions. This reflects the distinct compositions of the ore-forming fluids and is also shown by differences in the mineral assemblage formed during the main muscovite selvage formation stage and distinct major- and trace-element contents of muscovites of selvages associated with cassiterite from these deposits. Muscovite of selvages from $\mathrm{Sn}>\mathrm{W}$-bearing quartz veins of Argozelo and Vinheiros are richer in $\mathrm{Nb}, \mathrm{Ta}, \mathrm{Sn}$ and $\mathrm{Cs}$ and poorer in $\mathrm{Fe}$ and $\mathrm{Li}$ than muscovite of selvages from $\mathrm{W}>$ Sn-bearing quartz veins from Panasqueira (Neiva, 1982, 1987b).

Combined stable isotope and fluid inclusion studies provide the main evidence for a genetic relation of hydrothermal tin ores with associated granites (Heinrich, 1990). The $\mathrm{Sn}>\mathrm{W}$ - and $\mathrm{W}>$ Sn-bearing quartz veins are mainly associated with S-type granites. Their selvage muscovite and associated cassiterite are related to different S-type granites originated by partial melting of sedimentary materials. Differences in these source materials, magmatic differentiation and fractionation of elements into hydrothermal fluids are certainly responsible for the distinction found between cassiterites and also between associated muscovites from $\mathrm{Sn}>\mathrm{W}$ - and $\mathrm{W}>$ Sn-bearing quartz veins. The chemical compositions of cassiterite and intergrown muscovite from the two vein types can be used for distinguishing the two ore deposit types, providing hints for exploration.

In tin deposits and also in tungsten deposits, fluid inclusions in minerals of the oxide-silicate stage are liquid-vapour or aqueous-carbonic. There is evidence for boiling or separation of $\mathrm{CO}_{2}-\left(\mathrm{CH}_{4-}\right)$-rich phase, suggesting fairly reduced fluids. $\mathrm{Na}$ dominates over $\mathrm{K}$ and $\mathrm{Ca}$. Chloride is the dominant anion. In most tin deposits, fluid inclusions associated with cassiterite are saline ( 5 to 50 equivalent wt.\% $\mathrm{NaCl}$ ), have homogenization temperatures ranging from $220^{\circ} \mathrm{C}$ to $500^{\circ} \mathrm{C}$ and fluid pressures varying from 200 to 600 bars (Heinrich, 1990). In the tungsten deposits lacking significant Sn, fluids associated with wolframite have salinities generally $<15$ wt.\% equiv. $\mathrm{NaCl}$ (but in some cases up to 55 wt.\%), temperatures from $200{ }^{\circ} \mathrm{C}$ to $500{ }^{\circ} \mathrm{C}$ and 
pressures of 200 to 1500 bars (Wood and Samson, 2000).

Unfortunately, fluid inclusion and stable isotope studies are not available for most of the Portuguese $\mathrm{Sn}>\mathrm{W}$ - and $\mathrm{W}>$ Sn-bearing quartz veins studied. Magmatic fluids occurred in the early oxide-silicate stage at Panasqueira, since a high $\delta^{18} \mathrm{O}$ quartz value $(13 \%$ ) was found for a relatively unaltered quartz megacryst of likely primary magmatic origin (Kelly and Rye, 1979), and $\delta^{18} \mathrm{O}$ for primary magmatic waters from this deposit is around $11 \pm 1 \%$ (Polya et al., 2000). This is similar to the whole-rock $\delta^{18} \mathrm{O}$ values of S-type granites associated with Sn- and W-deposits and occurrences in northern and central Portugal (Neiva, 2002). It is most likely that magmatic fluids were important in this main stage of ore formation in all $\mathrm{Sn}>\mathrm{W}$ - and $\mathrm{W}>\mathrm{Sn}$-bearing quartz veins. However, oxygen isotopes alone are insufficient to distinguish a magmatic fluid that was equilibrated with a hot solid granite at $T>400-500{ }^{\circ} \mathrm{C}$ and fluid/rock $<0.1$ from a meteoric fluid that underwent the same equilibration (Heinrich, 1990). The hydrogen isotope data indicate two different waters, each of uncertain origin, involved in the oxide-silicate stage at Panasqueira (Kelly and Rye, 1979). The combination of oxygen and hydrogen isotopic data of this ore-forming stage fluid is explained by isotopic exchange of meteoric water with the Panasqueira granite (Polya et al., 2000). The chemical characteristics of these fluids are consistent with meteoric fluids equilibrated with a granitic mineral assemblage at similar temperatures, around $350{ }^{\circ} \mathrm{C}$ (Polya, 1989).

During the Panasqueira oxide-silicate stage, the filling temperatures range from 230 to $360{ }^{\circ} \mathrm{C}$ and salinities range from about 5 to $10 \mathrm{wt} \% \mathrm{NaCl}$ equiv., both showing distinct fluctuations that do not correlate with each other, suggesting fluid mixing (Kelly and Rye, 1979; Bussink et al., 1984). All inclusion data (Kelly and Rye, 1979; Bussink et al., 1984) point to low total pressures $<1$ kbar (Polya et al., 2000) corresponding to shallow depths and consequently the involvement of meteoric water at this stage. This is supported by fluid densities below unity (Kelly and Rye, 1979). Extensive stable isotope $\left(\delta \mathrm{D}, \delta^{18} \mathrm{O}, \delta^{13} \mathrm{C}, \delta^{15} \mathrm{~N}\right)$ studies (Kelly and Rye, 1979; Bussink, 1984; Bussink et al., 1984; Noronha et al., 1992) suggest that the main oxide-silicate stage fluids are mixtures of meteoric water and magmatic hydrothermal fluids (Burnard and Polya, 2004). However, Clark (1964) and Kelly and Rye (1979) argue for the importance of magmatic fluids in the early stages of ore formation. Wolframite from Panasqueira contains 13 to $23 \mathrm{~mol} \%$ hübnerite (Table 3 ) and many single crystals are homogeneous in composition. The range in compo- sition within individual crystals is typically $2 \mathrm{~mol} \%$ hübnerite, which is taken to indicate the relatively homogeneous character of the source fluids. Therefore, if mixing occurred it would have taken place at depth.

In the $\mathrm{W}>$ Sn-bearing quartz from Vale das Gatas, there are heterogeneous crystals of wolframite (Fig. 2d), other complex oscillatory zoned crystals (Table 4), and also single crystals containing a core and a rim which show a sharp contact and homogeneous crystals (Table 4). Wolframite specimens from this deposit have the widest compositional range - from 18 to $96 \mathrm{~mol} \%$ hübnerite. Different wolframite compositions are found in the same quartz vein crosscutting the same host rock and sharing the same parent granite, a fact which may be attributed to local changes in fluid composition (Nakashima et al., 1986). Fluid inclusion studies of quartz associated with wolframite from Vale das Gatas deposit give a mean homogenisation temperature of $225 \pm 6{ }^{\circ} \mathrm{C}$, which is not corrected for lithostatic pressure and therefore is regarded as minima and a salinity of $6 \mathrm{wt} . \% \mathrm{NaCl}$ equivalents (Gaspar et al., 1987), i.e., roughly similar to those from Panasqueira. Therefore, the distinct compositions of wolframite from Vale das Gatas and Panasqueira are not controlled by the temperature and depend on the fluid compositions.

In the $\mathrm{W}>$ Sn-bearing quartz veins from Carris, there are two different generations of crystals, with distinct homogeneous compositions. The earlier generation contains $91 \mathrm{~mol} \%$ hübnerite, while the younger contains $27 \mathrm{~mol} \%$ hübnerite, bears scheelite inclusions and partially replaces the scheelite (Table 4). The change in hübnerite component in wolframite results from a change in the fluid composition. The precipitation of scheelite after the earlier generation of wolframite implied an increase in the $\mathrm{Ca} / \mathrm{Fe}$ ratio of the ore-forming solution concomitant with cooling (Wood and Samson, 2000). The precipitation of the younger generation of wolframite resulted from the decrease in this $\mathrm{Ca} / \mathrm{Fe}$ ratio of the solution accompanying further cooling. The $\mathrm{W}>\mathrm{Sn}$ bearing quartz veins from Carris cut an I-type granite. Wolframite from Carris is not compositionally distinct from the wolframite in other Portuguese deposits associated with S-type granites. This may be related to the fact that the I-type granite is only slightly more oxidized than S-type granites. The main opaque mineral is ilmenite, as in the S-type granites; magnetite is rare (Neiva, 1993).

In most of the Panasqueira $\mathrm{W}>$ Sn-bearing quartz veins studied, wolframite has a relatively low range of composition (Table 3). Heterogeneous crystals of wolframite also occur in the $\mathrm{W}>$ Sn-bearing quartz veins from Filharoso and Panasqueira. Inner Mn-rich patches 
are observed within otherwise relatively homogeneous wolframite (Table 3 ). This suggests that these core patches represent an early stage of wolframite precipitation, at a higher crystallization temperature relative to that for the enclosing Mn-poor wolframite.

Some wolframite crystals from the $\mathrm{Sn}>\mathrm{W}$-bearing quartz veins from Argozelo are heterogeneous (Fig. 5e, f); others display complex or oscillatory zoning and have a significant compositional range from 33 to $67 \mathrm{~mol} \%$ hübnerite component (Table 3). This zoning is certainly mainly controlled by $\mathrm{Mn} / \mathrm{Fe}$ variations in the mineralizing fluid.

Niobium is also found in significant concentrations within wolframites from the $\mathrm{Sn}>\mathrm{W}$-bearing quartz veins of Argozelo (Table 3, Fig. 7b) and the W $>$ Snbearing quartz veins from Panasqueira and Vale das Gatas (Tables 3 and 4; Fig. 7b, c). There is, therefore, no significant difference between the major and minor elements of wolframites in the two types $(\mathrm{Sn}>\mathrm{W}$ - and $\mathrm{W}>\mathrm{Sn}$ ) of veins. This is attributed to the fact that fluids responsible for wolframite precipitation in both vein types are relatively similar.

The decrease in $\mathrm{Nb}$, and concordant increase in $\mathrm{W}$ from core to rim in three single crystals from Panasqueira (Table 3, Fig. 7d, e), the negative correlations between $\mathrm{Nb}$ and $\mathrm{W}$ (Fig. $7 \mathrm{~b}, \mathrm{c})$ and between $\left(\mathrm{Nb}^{5+}+\mathrm{Fe}_{\text {calc }}^{3+}\right)$ and $\left(\mathrm{W}^{6+}+\mathrm{Fe}_{\mathrm{calc}}^{2+}+\mathrm{Mn}^{2+}\right)$ (Fig. 7f) and the fact that the increase in the $\mathrm{Nb}$ content of wolframite causes an increase in the unit cell parameters (Polya, in press), supporting the view that $\mathrm{Nb}$ occurs in solid solution and is incorporated into the wolframite structure by the coupled substitution $\left[(\mathrm{Fe}, \mathrm{Mn})^{2+}, \mathrm{W}^{6+}\right] \mathrm{D}\left(\mathrm{Fe}^{3+}, \mathrm{Nb}^{5+}\right)$.

The wolframite from Panasqueira shows uniform major element chemical composition over large distances of up to $2 \mathrm{~km}$, but significant variations in its $\mathrm{Nb}$ content occur, which are related to their more local enrichment in $\mathrm{Fe}^{3+}$ (Table 3). The $\mathrm{Fe}^{3+}$-rich wolframite which contains significant $\mathrm{Nb}$ probably precipitated from oxidized fluids. The $\delta^{18} \mathrm{O}$ for the wolframite from this deposit ranges from 4.9 to $5.8 \%$ (Kelly and Rye, 1979).

Wolframite from the $\mathrm{Sn}>\mathrm{W}$-bearing quartz veins from Argozelo contains up to $0.94 \mathrm{wt} . \% \mathrm{Nb}_{2} \mathrm{O}_{5}$ (Table 3), while cassiterite from the same deposit contains up to $1.12 \mathrm{wt} . \%$ $\mathrm{Nb}_{2} \mathrm{O}_{5}$ in the darker zones (Table 1), with exsolved columbite and ixiolite. Wolframite is later than cassiterite and the $\mathrm{Nb}$ - and Ta-bearing oxide minerals. Therefore, the fluids responsible for wolframite precipitation had a lower $\mathrm{Nb}$ content than the fluids associated with cassiterite precipitation, attributed to the change in composition of fluids with decreasing temperature.

Cassiterite from $\mathrm{W}>$ Sn-bearing quartz veins commonly has a low $\mathrm{Nb}$ content of up to $0.36 \mathrm{wt} . \% \mathrm{Nb}_{2} \mathrm{O}_{5}$
(Neiva, 1996). Cassiterite from the deposits of Panasqueira and Vale das Gatas contains only up to $0.01 \mathrm{wt} . \%$ $\mathrm{Nb}_{2} \mathrm{O}_{5}$ (Table 1); their rutile inclusions contain up to 0.59 and $5.42 \mathrm{wt} . \% \mathrm{Nb}_{2} \mathrm{O}_{5}$, respectively (Table 2). Wolframites from these two deposits have up to 1.88 and $0.63 \mathrm{wt} . \%$ $\mathrm{Nb}_{2} \mathrm{O}_{5}$ (Tables 3 and 4), respectively. The $\mathrm{Nb}$ content of the mineralizing fluids decreased from the time of rutile precipitation to that of cassiterite. The fluids responsible for wolframite precipitation had a higher $\mathrm{Nb}$ content than the fluids associated with cassiterite precipitation.

The unaltered granite from Panasqueira, obtained from a drillcore, contains $23 \mathrm{ppm} \mathrm{Nb}, 15 \mathrm{ppm} \mathrm{Sn}$ and $3 \mathrm{ppm} \mathrm{W}$ (Neiva, 1987a). The unaltered host schist contains from 11 to $14 \mathrm{ppm} \mathrm{Nb}$, Sn below the detection limit and $\mathrm{W}$ up to 3 ppm (Polya, 1989). Consequently, the host schist has lower contents of these three elements than the granite. Therefore, a meteoric fluid could not have efficiently extracted from schist higher contents of Nb, Sn and $\mathrm{W}$ that those provided by differentiation of the granite magma to originate the magmatic hydrothermal fluids. So, the hydrothermal fluids responsible for the cassiterite and wolframite precipitations must have been dominantly magmatic. Muscovite intergrown with wolframite has distinct major and trace element contents from the muscovite of selvages associated with cassiterite (Neiva, 1987b), indicating that they are derived from two different fluids. Two waters were present in the oxide-silicate stage, one with $\delta \mathrm{D}$ values in the range -67 to $-124 \%$ in cassiterite and arsenopyrite and the other with $\delta \mathrm{D}$ values of from -41 to $-63 \%$ in quartz and wolframite at the same temperature range from 230 to $360{ }^{\circ} \mathrm{C}$ (Kelly and Rye, 1979). Data on helium trapped in wolframite and arsenopyrite indicates that these ore minerals are derived from magmatic fluids of mantle origin (Burnard and Polya, 2004), but there is no field evidence of a late basic intrusion in the area. Certainly these two waters are of magmatic origin and of different ages, because the associated muscovite with cassiterite is $296.3 \pm 0.6 \mathrm{Ma}$, while the muscovite intergrown with wolframite is $292.9 \pm$ $0.7 \mathrm{Ma}$, synchronous with greisenization of the granite cupola at $292.1 \pm 0.4 \mathrm{Ma}$ (Snee et al., 1988). In the W $>$ Snbearing quartz veins, $\mathrm{Nb}$ content of wolframite is higher than that of cassiterite, because these ore minerals precipitated from two distinct magmatic hydrothermal ore-forming fluids. Based on the field evidence these fluids will be derived from the associated granite (e.g., Baker et al., 2005).

At Panasqueira, greisenization occurred after the quartz veins started to be formed. Fluids causing greisenization would have a similar composition to those responsible for wolframite precipitation within the thick quartz veins as they would have been contemporaneous, which is 
suggested by the similar ages of muscovite from greisenized granite and muscovite intergrown with wolframite within the quartz veins (Snee et al., 1988). These muscovites have similar trace element contents, but the latter does not contain $\mathrm{Nb}$, while the former has $121 \mathrm{ppm} \mathrm{Nb}$ (Neiva, 1987a,b). $\mathrm{Nb}$ is easier retained in wolframite than in the intergrown muscovite within the vein; wolframite does not occur in the greisenized granite.

The high tin concentrations can be transported as $\mathrm{Sn}(\mathrm{II})-\mathrm{Cl}$ complexes by an acid fluid at temperatures $<400{ }^{\circ} \mathrm{C}$ (Heinrich, 1990). Cassiterite occurs in quartz veins, mainly intergrown with muscovite, to form selvages along the vein-schist contact, suggesting that the neutralizing reactions required for the precipitation of cassiterite (Heinrich, 1990) included the conversion of the wallrock biotite into muscovite. Carbonate dissolution from marble lenticles in the wallrock will also assist this reaction (Eugster, 1985). At Carris and Vale das Gatas, the quartz veins intruded granites and the main mechanism for acid neutralization is conversion of wallrock feldspar into muscovite (Eugster, 1985). This interpretation is supported by the muscovite selvages associated with cassiterite along the vein-granite contact. Tungsten has a different behaviour from that of tin (Heinrich, 1990). It is carried as $\mathrm{H}_{2} \mathrm{WO}_{4}, \mathrm{HWO}_{4}^{-}, \mathrm{HWO}_{4}^{2-}, \mathrm{HWO}_{4}^{2-}$ and alkali-tungstate ion pairs (Wood and Samson, 2000). As wolframite occurs mainly within the quartz veins, the wallrock reaction is not necessary for the precipitation of wolframite by cooling of an $\mathrm{Fe}-\mathrm{W}$-bearing fluid (Heinrich, 1990).

\section{Conclusions}

1. Cassiterite occurs mainly intergrown with muscovite, forming selvages at quartz-wallrock contacts. In the $\mathrm{Sn}>\mathrm{W}$-bearing quartz veins, there is a chemical distinction between alternating darker and lighter zones of cassiterite and the darker zones present exsolutions of columbite and ixiolite. In the $\mathrm{W}>$ Sn-bearing quartz veins, these zones of cassiterite show a similar composition and contain rutile and rare ilmenite inclusions.

2. Cassiterite from $\mathrm{Sn}>\mathrm{W}$ - and cassiterite from $\mathrm{W}>$ Sn-bearing quartz veins are chemically distinct, because they largely are derived from magmatic hydrothermal fluids of different compositions. The difference in source is also responsible for the presence of columbite-tantalite and ixiolite in the $\mathrm{Sn}>\mathrm{W}$-veins and rutile and ilmenite in the $\mathrm{W}>\mathrm{Sn}$-veins, as well as the different major and trace element compositions of muscovite selvages associated with cassiterite from the two vein-types.

3. Precipitation of cassiterite at the quartz vein-schist contact required neutralizing reactions which converted biotite from schist into muscovite and carbonate dissolution from marble lenticles within the schist.

4. The conversion of granite feldspar into muscovite is believed to be the main mechanism for acid neutralization necessary for precipitation of cassiterite at the quartz vein-granite contact.

5. Wolframite occurs in either homogeneous crystals or zoned crystals. Rarely, inner patches rich in a hübnerite component are found in crystals. Complex oscillatory zoned crystals and others showing and increase in $\mathrm{Fe}$ and decrease in $\mathrm{Mn}$ from core to rim also occur.

6. There is no chemical distinction with respect to major and trace elements between the wolframite in the two types of quartz vein, suggesting that wolframite is derived from magmatic hydrothermal fluids of relatively similar composition.

7. In most mineralized quartz veins, wolframite has a homogeneous major element composition over large distances, which can be attributed to a relatively uniform composition of the fluids.

8. Different generations of wolframite were found in the Carris and Vale das Gatas mines. In each deposit, the youngest generation has the lowest $\mathrm{Mn} / \mathrm{Fe}$ ratio, controlled by $\mathrm{Mn} / \mathrm{Fe}$ variation in fluid.

9. Wolframites from the $\mathrm{Sn}>\mathrm{W}$-bearing quartz veins from Argozelo and $\mathrm{W}>$ Sn-bearing quartz veins from Panasqueira and Vale das Gatas have significant $\mathrm{Nb}$ contents, which are negatively correlated with $\mathrm{W}$. A very good negative correlation was also found between $\left(\mathrm{Nb}^{5+}+\mathrm{Fe}_{\text {calc }}^{3+}\right)$ and $\left(\mathrm{W}^{6+}+\mathrm{Fe}_{\text {calc }}^{2+}+\mathrm{Mn}^{2+}\right)$ within these wolframites. $\mathrm{The}^{3+} \mathrm{F}^{3+}$ and $\mathrm{Nb}$-rich wolframite probably precipitated from more oxidized fluids.

10. At Panasqueira, cassiterite and wolframite precipitated from two distinct magmatic hydrothermal fluids, each having distinct $\delta \mathrm{D}$ values. This is supported by the distinct ages and major and trace element compositions of the associated muscovites. Wolframite precipitated from the younger fluid.

11. At Panasqueira and Vale das Gatas, cassiterite has a lower $\mathrm{Nb}$ content than its rutile inclusions. Wolframite has a higher $\mathrm{Nb}$ content than the earlier cassiterite, which is attributed to the fact that both ore-minerals are derived from two distinct magmatic fluids. 
12. Wolframite from these $\mathrm{W}>\mathrm{Sn}$-bearing quartz veins precipitated from a fluid of relatively similar composition to that resulting from the evolution of the fluid responsible for cassiterite precipitation in the $\mathrm{Sn}>\mathrm{W}$-bearing quartz veins.

\section{Acknowledgements}

Thanks are due to Prof. J.M. Cotelo Neiva for his help in collecting the samples, to Eng. R.A. Naique for the wolframite samples from Panasqueira, and to Eng. L.J.A. Lopes for information on the location of these samples relative to faults. Thanks are also due to Prof. M.M. Machado Leite and Dr. J.M. Farinha Ramos for access to the electron microprobe at the Instituto Geológico e Mineiro, S. Mamede de Infesta. Prof. C.A. Leal Gomes assisted with the photographs and Dr. Elsa Ribeiro helped with use of the scanning electron microscopy at Minho University. Financial support from the Geosciences Centre at Coimbra University is also acknowledged. This paper benefited from the helpful comments of Profs. Jorge Bettencourt, Robert Linnen and Nigel J. Cook.

\section{References}

Baker, T., Pollard, P.J., Mustard, R., Mark, G., Graham, J.L., 2005. A comparison of granite-related tin, tungsten and gold-bismuth deposits: implications for exploration. SEG Newsletter 61 (5), $10-17$.

Burnard, P.G., Polya, D.A., 2004. Importance of mantle derived fluids during granite associated hydrothermal circulation: $\mathrm{He}$ and $\mathrm{Ar}$ isotopes of ore minerals from Panasqueira. Geochimica et Cosmochimica Acta 68, 1607-1615.

Bussink, R.W., 1984. Geochemistry of the Panasqueira tungsten-tin deposit, Portugal. Geology Ultraiectiva 33170 pp.

Bussink, R.W., Kreulen, R., de Yong, A.F.M., 1984. Gas analyses, fluid inclusions and stable isotopes of the Panasqueira W-Sn deposit, Portugal. Bulletin de Minéralogie 107, 703-713.

Carneiro, F.S., 1959. A riqueza da indústria extractiva metropolitana. Estudos, Notas e Trabalhos do Serviço de Fomento Mineiro 13, 65-215.

Černý, P., Ercit, T.S., 1989. Mineralogy of niobium and tantalum; crystal chemical relationships, paragenetic aspects and their economic implications. In: Möller, P., Černý, P., Saupé, F. (Eds.), Lanthanides, Tantalum and Niobium. Springer-Verlag, Heidelberg, Germany, pp. 27-79.

Černý, P., Chapman, R., Ferreira, K., Smeds, S.-A., 2004. Geochemistry of oxide minerals of $\mathrm{Nb}, \mathrm{Ta}, \mathrm{Sn}$ and $\mathrm{Sb}$ in the Varuträsk granitic pegmatite, Sweden: The case of an "anomalous" columbite-tantalite trend. American Mineralogist 89, 505-518.

Černý, P., Ercit, T.S., Wise, M.A., 1992. The tantalite-tapiolite gap: natural assemblages versus experimental data. Canadian Mineralogist 30, 587-596.

Černý, P., Roberts, W.L., Ercit, T.S., Chapman, R., 1985. Wodginite and associated oxide minerals from the Perless pegmatite, Pennington County, South Dakota. American Mineralogist 70, 1044-1049.
Clark, A.H., 1964. Preliminary study of temperatures and confining pressures of granite emplacement and mineralization, Panasqueira, Portugal. Institute Mining Metallurgy Transactions 73, 813-824.

Cotelo Neiva, J.M., 1944. Jazigos portugueses de cassiterite e volframite. Comunicações dos Serviços Geológicos de Portugal 25, 1-251.

Cotelo Neiva, J.M., Soares Carneiro, F., Correia Neves, J.M., 1956. Pseudomorphoses de scheelite en ferbérite. Estudos, Notas e Trabalhos do Serviço de Fomento Mineiro XI, 1-8.

Eugster, H.P., 1985. Granites and hydrothermal ore deposits. A geochemical framework. Mineralogical Magazine 49, 7-23.

Foxford, K.A., Nicholson, R., Polya, D.A., 1991. Textural evolution of $\mathrm{W}-\mathrm{Cu}-\mathrm{Sn}$ bearing hydrothermal quartz veins at Minas da Panasqueira, Portugal. Mineralogical Magazine 55, 435-445.

Gaspar, O., Bowles, J.F., Shepherd, T.J., 1987. Silver mineralization at the Vale das Gatas tungsten mine, Portugal. Mineralogical Magazine 51, 305-310.

Gu, V.Q.G., Schröcke, H., 1986. Trace elements in wolframite and their crystal-chemical correlations. Chemie der Erde 45, 113-127.

Heinrich, C.A., 1990. The chemistry of hydrothermal tin(-tungsten) ore deposition. Economic Geology 85, 457-481.

Kelly, W.C., Rye, R.O., 1979. Geologic, fluid inclusion, and stable isotope studies of the tin-tungsten deposits of Panasqueira, Portugal. Economic Geology 74, 1721-1822.

Mignardi, S., Ferrini, V., Masi, U., Nabais Conde, L., Sousa, M.B., 1998. Significance of the major and trace-element contents of wolframite from the deposits of Panasqueira and Vale das Gatas. In: Hagni, R.D. (Ed.), Proceedings, Ninth Quadrennial IAGOD Symposium E. Schweizerbart Verlagsbuchlandlung, Stuttgart, Germany, pp. 448-475.

Nakashima, K., Watanabe, M., Soeda, A., 1986. Regional and local variations in the composition of the wolframite series from SW Japan and possible factors controlling compositional variations. Mineralium Deposita 21, 200-206.

Neiva, A.M.R., 1973. Geochemistry of the granites and their minerals from the central area of northern Portugal. Memórias e Notícias do Museu e Laboratório Mineralógico e Geológico, Universidade de Coimbra 76, 1-43.

Neiva, A.M.R., 1982. Geochemistry of muscovite and some physicochemical conditions of the formation of some tin-tungsten deposits. In: Evans, A.M. (Ed.), Metallization Associated with Acid Magmatism. John Wiley and Sons Ltd, pp. 243-259.

Neiva, A.M.R., 1987a. Geochemistry of greisenized granites and metasomatic schist of tungsten-tin deposits in Portugal. In: Helgeson, H.C. (Ed.), Chemical Transport in Metasomatic Processes. NATO ASI Series. D. Reidel Publishing Company, pp. 681-699.

Neiva, A.M.R., 1987b. Geochemistry of white micas from Portuguese tin and tungsten deposits. Chemical Geology 63, 299-317.

Neiva, A.M.R., 1993. Geochemistry of granites and their minerals from Gerez Mountain, northern Portugal. Chemie der Erde 53, 227-258.

Neiva, A.M.R., 1996. Geochemistry of cassiterite and its inclusions and exsolution products from tin and tungsten deposits in Portugal. Canadian Mineralogist 34, 745-768.

Neiva, A.M.R., 2002. Portuguese granites associated with $\mathrm{Sn}-\mathrm{W}$ and $\mathrm{Au}$ mineralizations. Bulletin Geological Society of Finland 74 (1-27), 79-101.

Noronha, F., Dória, F., Dubessy, J., Charoy, B., 1992. Characterization and timing of the different types of fluids present in the barren and ore veins of the W-Sn deposit of Panasqueira, central Portugal. Mineralium Deposita 27, 72-79.

Novak, M., 1999. Cassiterite and tusionite as monitors of B and Sn behaviour in the elbaite pegmatite at Recice near Nove Mesto na 
Morave, western Moravia, Czech Republic. Neues Jahrbuch für Mineralogie Monatshefte 481-493.

Polya, D.A., in press. Chemical behaviour of tungsten in hydrothermal fluids and genesis of the Panasqueira $\mathrm{W}-\mathrm{Cu}-\mathrm{Sn}$ deposit, Portugal. Unpublished Ph.D. thesis, Victoria University of Manchester, U.K., $334 \mathrm{pp}$.

Polya, D.A., 1988. Compositional variation in wolframites from the Barroca Grande mine, Portugal: evidence for fault-controlled ore formation. Mineralogical Magazine 52, 497-503.

Polya, D.A., 1989. Chemistry of the main-stage ore-forming fluids of the Panasqueira $\mathrm{W}-\mathrm{Cu}(\mathrm{Ag})-\mathrm{Sn}$ deposit, Portugal: implications for models of ore genesis. Economic Geology 84, 1134-1152.

Polya, D.A., Foxford, K.A., Stuart, F., Boyce, A., Fallick, A.E., 2000. Evolution and paragenetic content of low $\delta \mathrm{D}$ hydrothermal fluids from the Panasqueira W-Sn deposit, Portugal: new evidence from microthermometric, stable isotope, noble gas and halogen analyses of primary fluid inclusions. Geochimica et Cosmochimica Acta 64, $3357-3372$.

Saraiva, M., 1971. A composição e distribuição das volframites no jazigo da Mina da Panasqueira (Portugal central). I Congresso
Hispano-Luso-Americano de Geologia Económica, Madrid 1971, Tomo II, Secção 4 Investigação Mineira 917-932.

Snee, L.W., Sutter, J.F., Kelly, W.C., 1988. Thermochronology of economic mineral deposits: dating the stages of mineralization at Panasqueira, Portugal, by high-precision ${ }^{40} \mathrm{Ar} /{ }^{39} \mathrm{Ar}$ age spectrum techniques on muscovite. Economic Geology 83, 335-354.

Vilela de Matos, A., in press. A geologia da região de Vila Real: evolução do Complexo Xisto-Grauváquico do Ordovícico e dos granitóides hercínicos e dos depósitos minerais associados. Unpublished Ph.D. thesis, University of Vila Real, Portugal, $312 \mathrm{pp}$.

Vilela de Matos, A.V., Sousa, M.B., 1994. Variação composicional das volframites e blendas do jazigo de Vale das Gatas (Norte de Portugal) e sua relação com os fluidos mineralizadores. Memórias e Notícias do Museu e Laboratório Mineralógico e Geológico da Universidade de Coimbra 118, 47-62.

Wood, S.A., Samson, I.M., 2000. The hydrothermal geochemistry of tungsten in granitoid environments: I. Relative solubilities of ferberite and scheelite as a function of T, $\mathrm{P}, \mathrm{pH}$ and $\mathrm{m}_{\mathrm{NaCl}}$. Economic Geology 95, 143-182. 